Yanko M. Hristov (Blagoevgrad)

\title{
Prisoners of War in Early Medieval Bulgaria (PRELIMINARY REMARKS)
}

From the first steps in establishing the First Bulgarian state along the Lower 1 Danube in the last quarter of the $7^{\text {th }}$ century, to its destruction under the blows of Emperor Basil II (976-1025), the dynamics, scale, nature, guidelines and characteristics of ethnic and territorial changes, military successes and failures, reforms, building ventures, religious life and cultural processes have received considerable scientific attention and plenty of scholarly researches. In this regard, the question of whether there could be found an aspect of the turbulent life of the Early Medieval Bulgaria, which needs further consideration, seems to have a predetermined response. Yet, clues relating to the captives during the wars, look as though they provide an opportunity for inflicting additional touches. The very moment with the prisoners of war, apart from not such a large number of publications specifically concerning the problem, is usually passed by ${ }^{1}$. The reasons are multifarious and the release of a special place to mention them in an article with limited length brings a serious danger of shifting its focus.

It is abundantly clear that the problem of prisoners of war in the Middle Ages goes beyond the lifetime of the First Bulgarian state. However, the voluntary recognition of narrower chronological and spatial boundaries is motivated by the

\footnotetext{
${ }^{1}$ With the exception of the last works of the author of this article, which will not be a subject to self-quoting; for publications narrowly focused on prisoners of war in Early Medieval Bulgaria, seе: Б. НиколовА, Неназован българо-византийски конбликт при хан Омуртаг, Епо 5.1/2, 1997, p. 63-76; Р. РАшев, Византийците в България до Покрбстването, [in:] Civitas DivinoHumana. In honorem annorum LX Georgii Bakalov, ed. Ц. СтеПАНов, В. ВАчковА, София 2004, p. 151-162; К. Станев, Депортираните ромеи в Бблгария 812-837 година, [in:] Оттука започва България. Материали от Втората национална конференция по история, археология и културен туризбм «Пбтуване към Бблгария», Шумен, 14-16 май 2010, еd. В. ГюзЕлев, Шумен 2011, p. 183-195; IDEм, Съдбата на ромейски войници, пленени при разгрома на император Никифор I, [in:] Кюстендилски четения 2007. Заедно или разделени. Европа на съюзите, тичностите и регионите, еd. В. Станев, София 2012, p. 25-33. Bulgarian scientists deal with aspects of the lives of prisoners of war in Byzantium, too: Л. СимеоновА, Разиифроване на езика на символите: „Реформите” на Лъв VI Мбдри в двориовия и публичния иеремониал, ИП 5/6, 1999, p. 3-20; EADEM, In the Depths of Tenth-Century Byzantine Ceremonial: The Treatment of Arab Prisoners of War at Imperial Banquets, BMGS 22, 1998, p. 75-104.
} 
peculiarities of the inter-Balkan relations, suggesting that no specifics in the relevant direction remain constant, even for the outlined period. The starting point, in an attempt to explore the issue of prisoners of war in Bulgaria is related to the state of the source basis - the origin, the level of awareness of authors, the time of writing, the volume, nature and informativeness of the preserved to our days written records. The clues are unevenly distributed in terms of information. With some exceptions, mostly for $707 / 708,754 / 755,763 / 764$ and 774 , the notices are concentrated around the events of 811-815/816, 837/838; 894-896, 917-30s and for a moment or two from the period of 971-1018. The vast majority of written evidence is the result of the creative efforts of the Byzantine authors. What is more, it comes to this significant diversity by type and kind of literature - longer or short chronicles, political and military manuals, hagiographic works, synaxarium notes, fragments of the epistolary heritage of Constantinople representatives of the political and intellectual elite, etc. ${ }^{2}$

The dominance of the Byzantine narratives predetermines an extremely important feature on the problem of prisoners of war in the Early Medieval Bulgaria. The reports are mainly about imperial subjects caught up in Bulgarian captivity, and to a much lesser extent about any other captives. For a number of aspects relating to the topic, some Proto-Bulgarian stone inscriptions appear to be productive ${ }^{3}$. With the development of the Old Bulgarian written tradition, after sheltering the students of Cyril and Methodius and the perception of the Slavonic Alphabet, further details are given by both the original works and the compilations based on the Byzantine texts. This is especially valid in the written law. Закон'ы соүдныи (The Court Law for the People) deserves a special attention. Its use as a data source in the respective direction is not quite seamless, because timing and place of issuance of the early Slavonic law monument is a subject of controversy ${ }^{4}$. Nowadays

\footnotetext{
${ }^{2}$ In this paper the quotes are based on the English translations of the relevant works. For narratives relating to the Early Medieval Bulgarian history, published in full, in larger parts or fragments cf. $F G H B$, vol. III-VII.

${ }^{3}$ В. БЕшевлиЕв, Първобългарски надииси, ${ }^{2}$ София 1992.

${ }^{4}$ Cf. J. VAšica, Origine Cyrilo-Methodienne du plus ancient code slave dit «Zakon Sudnyj Ljudem», Bsl 12, 1951, p. 154-174; М. АндреЕв, Кбм въпроса за произхода и същността на Законъ соудьй людьмь, ГСУ.ЮФ 49, 1957, p. 1-60; J. VAšıCA, K lexiku Zakona sudného ljudem, SR 10.1/4, 1957, p. 61-66; М. Андревв, Законъ соудый людьмг - стробългарски правен паметник, ПМи 1, 1958, р. 13-27; В. ГАнев, Законъ соудный людьмъ. Правно-исторически и правно-аналитични проучвания, София 1959; С. Троицки, Святой Мефодий как славянский законодатель, [in:] IDEм, Богословские труды, vol. II, Москва 1961, p. 83-141; J. VAšıсA, K otázce puvodu Zakona sudného ljudem, Sla 30, 1961, p. 1-19; М. Андреєв, Нови проучвания и нови теории относно произхода на Законъ соудый людьмъ, ГСУ.ЮФ 55, 1964, p. 29-72; V. Рвосни́zка, Materiály a diskuse. Tř́ nové marné po kusy o bulharského a makedonského pi̊vodu Zakona sudného ljudem, Sla 33, 1964, p. 262-267; С. Троицки, Да ли је «Закон судый людем» составио свети Методије или бугарски кнез Борис?, ИЧ 14/15, 1965, p. 505-516; V. Рвосна́zка, Le Zakonъ sudnyjъ ljudømъ et la Grande Moravie, Bsl 28, 1967, p. 359-375; 29.1, 1968, p. 112-150; Zakon sudnyi liudem. (Court Law for the
} 
discussions are far from being as active as in the 1950s and 1960s $\mathrm{s}^{5}$ However, it feels as if there are still a number of unresolved issues. Among the most important ones are those related to its distribution, application and the possible revisions and additions. Worries when using Закон' соүдныи людындъ, in reviewing the situation in the Bulgarian lands in late $9^{\text {th }}-10^{\text {th }}$ century, melt away due to the fact that the translated Byzantine legal literature sets a public framework and norms at the time of the rulers Symeon (893-927) and Peter (927-969) ${ }^{6}$.

The mentioned predominance of Byzantine texts complemented by the influence of Greek vocabulary over Proto-Bulgarian epigraphic monuments and Slavic literature are the reason for making another very important point. The contemporary conceptions of prisoners of war and their distinction from kidnapped, deported and abused during the time of war (or after that) captives non-combatants difficultly finds a direct medieval parallel. The language of captivity gravitates

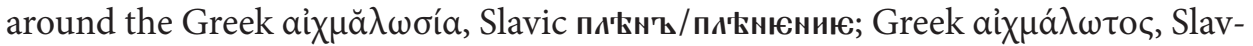

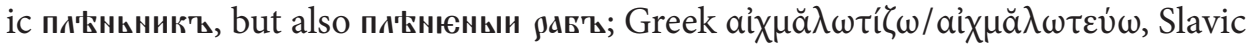

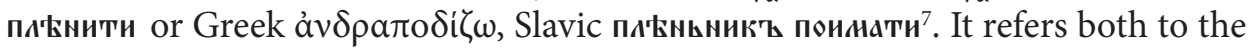
survived fighters after a battle falling into enemy hands, and to the abducted civilians, regardless of gender, age and social status. Proceeding namely from a similar

People), ed. et trans. H.W. Dewey, A.M. Kleimola, MSM 14, 1977, p. V-XV; Ф. МилковА, Законбт за съдене на хората - старобългарски паметник, [in:] Втори международен конгрес по българистика, vol. VI, ed. Х. Христов, София 1987, p. 692-708.

${ }^{5}$ Ch.K. Papastathis, On the «Saint Constantine» of the Zakon Sudnyj Ljudem, Bsl 56.3, 1995, p. 557-559; C. Gallagher, Church Law and Church Order in Rome and Byzantium: A Comparative Study, Aldershot 2002 [= BВOM, 8], 106-107; К.А. МАксимович, Древнейший памятник славянского права «Закон судный людем»: композииия, переводческая техника, проблема авторства, BB 61 (86), 2002, р. 24-37; ІDЕм, Закон'ь соүдныи аюдынты. Источниковедческие и тингвистические аспекты исследования славянского юридического памятника, Москва 2004, р. 7-23; К. ИлиевСКА, Законъ соүданыи аюдыл'ъ, Скопје 2004, p. 10-40; D. NAjDenova, Cyrillo-Methodian Juridical Heritage in Mediaeval Bulgaria, [in:] Poznávanie kultúrneho dedičstva sv. Cyrila a Metoda. Monografia príspekov z medzinárodnej konferencii Nitra, 3 júl 2007, ed. J. MichaLov et al., Nitra 2007, p. 76-93.

${ }^{6}$ Р. Чолов, Византийското право в Средновековна България, [in:] Втори международен конгрес по българистика, vol. VI, ed. Х. Христов, София 1987, p. 546-556; Д. НАЙденОвА, Преводни византийски законови текстове в средновековна България, СБАН 121.5, 2008, p. 30-36; ЕАDЕм, Cyrillo-Methodian Juridical Heritage in Mediaeval Bulgaria..., p. 81-88; вADEм, Правните паметници в Първото българско изарство, ИБ 9.1/2, 2005, p. 136-163 (142-144 in particular).

7 Ћ. ДАничић, Рјечник из кюижевних старина српских, vol. II, Л-П, Београд 1863, p. 318-319; F. Mikloshich, Lexicon Palaeoslovenico-Graeco-Latinum, Vindobonae 1862-1865, p. 577-578; Г. Дьяченко, Полный церковно-славянский словарь, Москва 1900, p. 434; И. СрезневскИй, Материалы для словаря древнерусского языка по письменным памятникам, vol. II, Л-П, Санкт-

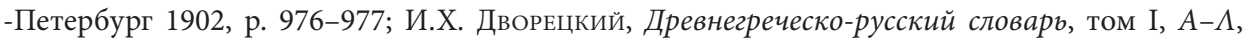
Москва 1958, p. 58-59; Э. БЛАГОвА, Р.М. ЦЕЙТлин, Р. ВечеРКА, Староставянский словарь (По рукописям X-ХІ веков), Москва 1994, р. 452; Д. Иванова-МирчевА, А. ДАвИДКОв, Ж. Икономова, Старобългарски речник, vol. II, О-У, София 2009, p. 223-224. 
feature in the texts, it has been relatively recently emphasized by the Israeli scholar Youval Rotman that during the Middle Ages in the Eastern Mediterranean with the general definition of a captive were identified not only prisoners of war - warriors of any rank, direct participants in the fighting - but also residents of the region of the military hostilities, kidnapped by enemy armies. This happens most often in ruins and raids on a foreign territory or after victorious battles ${ }^{8}$.

$* * *$

At least in theory, after even a glimpse at the military actions and the territorial range, of course taking into account its changes, the captives in Early Medieval Bulgaria in general should have come from the Balkans - imperial subjects, dwellers of the so-called and the second quarter of the $9^{\text {th }}$ century onwards includes principalities of Serbs and Croats. To the abovementioned there can also be added prisoners of war from the conflicts in the North-eastern Bulgarian periphery in the steppes on the Lower Dnester (or/and Bug) River and Black Sea Coast, but also those in the Carpathian Mountains and the Middle Danube.

For the period $8^{\text {th }}-10^{\text {th }}$ century the imperial subjects fallen into captivity among the Bulgarians are mostly (not only) from the Upper Thracian Plain, Southern Black Sea Coast, the plains of eastern Thrace - between Adrianople and Constantinople, or the settlements in the foothills of the Eastern Rhodopes, Strandzha and Sakar. This specificity is maintained until the blows on Pliska and Preslav State Centre of Rus' and Byzantines in 969-972, and the creation of a new one in the western parts of the Tzardom. From the last quarter of the tenth century, Sofia area, the valley of the Struma River, Thessalonica and Thessaly are the main areas in which there are caught Byzantine prisoners of war9. Narratives indicate that the

${ }^{8}$ Y. Rotman, Byzantine Slavery and the Mediterranean World, trans. J.M. TodD, Cambridge 2009, p. 25-30; IDEM, Captif ou esclave? Entre marché d'esclaves et marché de captifs en Méditerranée medievale, [in:] Les esclavages en Méditerranée. Espaces et dynamiques économiques, ed. F.P. GuILlén, S. Trabelsi, Madrid 2012, p. 25-46.

${ }^{9}$ One of the earliest manifestations of the mentioned feature is the Battle of Anchialus in 708. In Chronography it is described as follows: As the army scattered in the fields like sheep to collect hay, the Bulgarian spies saw from the mountains the senseless disposition of the Romans. Gathering together like beasts, they suddenly attacked and inflicted great losses on the Roman flock, taking many captives, horses, and arms in addition to those they killed - The Chronicle of Theophanes Confessor: Byzantine and Near Eastern History A.D. 284-813, trans. C. Mango, R. Scott, Oxford 1997 (cetera: TheoPHANES), p. 525. Similar information concerning the mentioned battle: Nikephoros, Patriarch of Constantinople, Short History, ed., trans. et comm. C. Mango, Washington 1990 (cetera: NikePHOROs), p. 105. The quotations are based on the stated English translations. Minor differences that do not alter the meaning of captivity (captive; capture) and its later manifestations: Vita Lucae Iunioris Steiriotis, [in:] FGHB, vol. V, p. 232; Laudatio Photii Thessalonicensis, [in:] FGHB, vol. V, p. 315; Joannis Geometrae Carmina, [in:] FGHB, vol. V, p. 317-319; Кекавмен, Советы и рассказы. Поучение византийского полководиа ХІ века, ed. et trans. Г.Г. ЛитАврин, ${ }^{2}$ Санкт-Петербург 2003 (cetera: Кекавмен), р. 265-268; The History of Leo the Deacon: Byzantine Military Expansion in the Tenth Century. ed. et trans. A.-M. Talbot, D.F. Sullivan, Washington 2005 (cetera: Leo the Deacon), 
most numerous groups of captives throughout the existence of the First Bulgarian state are not the warriors but the abducted non-combatants ${ }^{10}$. In a recent publication, the young Bulgarian scientist Kamen Stanev notes that for now the archeological studies do not confirm the figures set out in the written monuments ${ }^{11}$. Of course, further excavations in present-day Bulgaria, Greece and Turkey can confirm as well as reverse the current perceptions of the demographic picture in the valleys of the rivers Maritsa, Tundža and Arda and Regina during the early Middle Ages. Due to the nature of the source basis, the geographical precision excluding the period of $812-814 / 815$, is not always attainable ${ }^{12}$. Following the intervention of Khan Omurtag (815-831) southwards, by the end of the pagan period there are reports of military actions by khans Malamir (831-836) and Presian (836-852) regarding the efforts from the early stages of the reign of Boris-Mihael the Baptizer (852-889). Unfortunately, the details are few. More information pertaining to prisoners of war and deported from shares of the Upper Thracian Plain, the Southern Black Sea or Eastern Thrace - from the foothills of Sakar, Strandzha and the lowland areas between Adrianople and Constantinople - is available in relation to the first war of Tzar Symeon (893-927) with Byzantium since 894-896. Highlighting the fact that among the captured warriors are members of the Imperial Guard - Khazars - just reminds one that there are other areas where the NinthCentury Bulgaria is likely to have prisoners of war ${ }^{13}$. And while, albeit with fuzzy

p. 128-131, 152-161, 177-201; John Skylitzes, A Synopsis of Byzantine History, 811-1057, trans. J. Wortley, Cambridge 2010 (cetera: John Skylitzes), p. 265-266, 273-294, 312-315.

${ }^{10}$ More notes about 712 Theophanes Confessor:

[...] the Bulgarians stealthily threw themselves upon the Bosporus by way of Philea and made great slaughter. They raided as far as the City and surprised many people who had gone across the water to celebrate opulent weddings and lavish luncheons with much silver plate and other equipment. They advanced as far as the Golden Gate and, after devastating all of Thrace, returned home unharmed with innumerable cattle - Theophanes, p. 532. Notices of another Bulgarian invasion in Thrace and reaching the Long Wall, looting and leading off captives, with no counteraction are present for 754/5. Theophanis Confessoris Chronographia, [in:] FGHB, vol. III, p. 270; For an English translation cf. Theophanes, p. 593.

${ }^{11}$ К. СтАнев, Тракия през ранното средновековие, Велико Търново 2012, р. 89-96, 106-109, 137-141, 163-166.

${ }^{12}$ Theophanis Confessoris Chronographia, p. 279-289; Scriptoris incerti historia de Leone Armenii Bardae filio, [in:] FGHB, vol. IV, p. 21-23; Georgii Monachi Chronikon, [in:] FGHB, vol. IV, p. 56; Leonis Gramatici Chronographia, [in:] FGHB, vol. V, p. 156; Pseudo-Symeonis Chronographia, [in:] FGHB, vol. V, p. 171-172; В. БЕшевлиЕв, Първобългарски..., p. 116-128, 130-131, 135-151, 153-163; В. ГюзЕлев, Българо-византийски диптих, [in:] Studia protobulgarica et mediaevalia europensia в чест на проф. В. Бешевлиев, ed. К. Попконстантинов et al., София 2003, p. 23-30 (cf. E. FolLIERI, I. DUJČEv, Un'acolutia inedita per i martiri di Bulgaria dell' anno 813, B 33, 1963, p. 71-106); Продолжатель Феофана. Жизнеописания византийских изарей, ed. Я.Н. ЛюбАрский, ${ }^{2}$ Санкт-Петербург 2009 (cetera: ПродОЛЖАТЕЛЬ ФЕОФАНА), p. 142-145.

${ }^{13}$ Leonis Choerosphactis Epistolae, [in:] FGHB, vol. IV, p. 176sqq; Theophanis Continuati Chronographia, [in:] FGHB, vol. V, p. 122; Leonis Gramatici Chronographia, p. 158; Georgius Monachus Continuatus, 
geographical specifics about the fate of Byzantine citizens, civilian and military, after discharging north of Haemus Mountain, however, there are certain orientations, then there are serious deficiencies in knowledge for the prisoners of war of the Bulgarian armies against enemies in the Northern Black Sea Coast and in the Middle Danube River ${ }^{14}$.

The presence of prisoners of war and abducted population of the Western Balkans in the First Bulgarian state is also reconstructed with difficulties. Despite the interest, research initiatives are highly dependent on the nature and quantity of the preserved to our days written evidence. The peculiarities of the source base on the history of the First Bulgarian state, and even to a larger extent quite modest volume of notices about the earliest history of Serbs from their settlement on the Balkans until the beginning of $11^{\text {th }}$ century, reduce the aspects that can be traced. A turning point for the middle and third quarter of the $9^{\text {th }}$ - the beginning of $10^{\text {th }}$ century is the treatise De Administrando Imperio composed by Emperor Constantine VII Porphyrogenitus (913/945-959), and for the end of the century to the early years of the $11^{\text {th }}$ century - the compilatory and not very precise chronicle (known by later copies) of an anonymous priest in the town of Bar, known in the scientific community as The Priest of Diocleia (or just Duklyan). Both works help to look at the geography of captivity to the interior of the peninsula, west of the Ibar River and the lands along the Dalmatian coast to the town of Zadar ${ }^{15}$.

[in:] FGHB, vol. VI, p. 139; Symeonis Magistri et Logothetae Chronicon, rec. S. WAHLGREN, Berolini -Novi Eboraci 2006, p. 275, 82 - 277, 138; Ioannis Scylitzae Synopsis Historiarum, rec. I. ThuRN, Berolini-Novi Eboraci 1973, p. 175, 75 - 177, 35.

${ }^{14}$ V. GJuzelev, Bulgarisch-Fränkische Beziehungen in der ersten Hälfte des 9 Jhs., BBg 2, 1966, p. 15-39; I. Вова, The Pannonian Onogurs, Khan Krum and the Formation of the Bulgarian and Hungarian Polities, BHR 11.1, 1983, p. 73-76; W. PoHL, Die Awaren. Ein Steppenvolk im Mitteleuropa 567-822 n. Chr., München 1988, p. 323-328; IDEM, A Non-Roman Empire in the Central Europe: The Avars, [in:] Regna and Gentes: The Relationship between Late Antique and Early Medieval Peoples and Kingdoms in the Transformation of the Roman world, ed. H.W. GoETz, Leiden-Boston 2003 [= TRW, 13], p. 571-595; T. Olajos, Le Lexique "Souda" a propos du khan bulgare Kroum et des Avars, [in:] Polihronia: Сборник в чест на проф. Иван Божилов, еd. И. Илиєв, София 2002, p. 230-235; P. Sophoulis, Containing the Bulgar threat: Byzantium's search for an ally in the former Avar territories in the Early Middle ages, BMd 2, 2011, p. 399-407; IDEM, Byzantium and Bulgaria, 775-831, Leiden-Boston 2012 [= ECEEMA, 16], p. 180-183, 210-211, 261.

${ }^{15}$ Citations are based on the English translation in the publication - Constantine Porphyrogenitus, De administrando imperio, vol. I, ed. et trans. G. Moravcsik, R.J.H. Jenkins, Washington 1967 (cetera: $D A I)$, p. 122-165. There are quite accessible translations into Serbian, Bulgarian and Russian: Константин ПорфИРогенит, Спис о народима, [in:] FBHPJS, vol. II, ed. et trans. B.B. FerJančić, Beograd 1959, p. 9-74; Constantini Porphyrogeniti De administrando imperio, [in:] FGHB, vol. V, p. 208-212; КоНСТАНТИН БАГРянОРОДНЫЙ, Об Управлении Империей. ed. et trans. Г.Г. Литаврин, А.П. Новосельцев, Москва 1991, p. 110-153. About so-called The Priest of Diocleia cf. Ф. Шишић, Летопис попа Дукљанина, Београд-Загреб 1928, р. 82-105, 122-126, 164, 179-184, 331-342; V. Mošın, Ljetopis popa Dukljanina, Zagreb 1950, p. 23-36; С. Мијушковић, Љетопис попа Дукљанина, Београд 1988, p. 9-89, 125-131. 
The mapping of areas from which captives were taken in the Early Medieval Bulgaria also highlights shades around their ethno-confessional profile. With the mentioned hesitations regarding their number in 755 and 778 respectively, the Emperors Constantine V (741-775) and Leo IV (775-780) accommodate Syrians and Armenians in Thrace, and in 807 and 810, the concentration of the population of eastern origin in the European areas of the Empire increased by migrations, organized by order of Emperor Nicephorus I (802-811). Theophanes Confessor openly called the descendants of Syrians and Armenians - heretics and distributors of Paulicianism ${ }^{16}$. Some of the authors perceive the details of such a nature awkward after the triumph of iconodule from 843 onwards. No wonder that they remain pushed into the background or completely concealed in Theophanes Continuatus and in the chronicle of John Scylitzes depicting legends about the origin of the founder of the Macedonian dynasty - Basil I (867-886), the forced downtime of his family in Bulgaria and the return of part of the Byzantine captives during the rule of Khan Omurtag ${ }^{17}$.

Mentioning the famous heterodox religious diversity allows to seek influence or absence of such of religious affiliation of policies of the Bulgarian ruling elite towards the Byzantine prisoners of war in the early Ninth-Century Bulgaria. When it comes to the time before the conversion initiatives of Knyaz Boris-Michael, the Byzantine authors emphasize upon the religious antagonism Pagans - Christians. The first ones are portrayed as savage barbarians and the latter ones are presented as defenseless and innocent victims of faith. This distinction somehow falters due to the well-known fate of the Bulgarian prisoners of war in 763. After the Battle of Anchialos between the troops of Khan Teletz (761-764) and Emperor Constantine V, the captured on the battlefield Bulgarian soldiers were brought to Constantinople and thrown to the crowd that killed them outside the curtain walls $^{18}$. Yet, descriptions of cruelties on behalf of Bulgarians against the fallen into

\footnotetext{
${ }^{16}$ The emperor Constantine transferred to Thrace the Syrians and Armenians whom he had brought from Theodosioupolis and Melitene and through them the heresy of the Paulicians spread about [...]; The emperor [Leo IV] [...] conveyed the Syrian heretics to Thrace and settled them there; In this year [809/810] Nicephorus, following the godless punishments [he had meted out] and intent on humiliating the army althogether, removed Christians from all the themata and ordered them to proceed to the Sklavinias after selling their estates - THEOPHANES, p. 593, 623, 667.

${ }^{17}$ ПродОЛЖАТЕЛЬ ФЕОФАна, p. 139-145; Јонn Sкylitzes, p. 117-119. The whole moment is represented with differences from Leo the Grammarian, the Continuatus of George Hamartolus, and later by John Zonaras cf. Pseudo-Symeonis Chronographia, p. 175; Leonis Gramatici Chronographia, p. 151, 155-157; Georgius Monachus Continuatus, p. 135-137; Ioannis Zonarae Epitomae Historiarum Libri XVIII, [in:] FGHB, vol. VII, p. 172.

${ }^{18}$ On 30 June of the It indiction, a Thursday, Teletzes came marching with multitude of nations and, battle having been joined, there was mutual slaughter for a long time. Teletzes was routed and fled. The battle lasted from the $5^{\text {th }}$ hour until evening. Great numbers of Bulgarians were killed, many were captured, and others deserted. Elated by this victory, the emperor celebrated a triumph in the City, which
} 
their hands Byzantines professing Christianity - warriors and civilians - require a special attention, and their a priori rejection is unnecessary. Far more productive is reporting the parameters of the situation in which violence manifests over the Byzantine captives. Due to the concentration of texts about the personality of Khan Krum (c. 800-814) and his successor/successors, the connection with the military actions between 807 and 815 is inevitable. The spiral of violence was rotated back in 808-809, after the Bulgarian success in the Battle of Serres and especially taking Serdica - where the Bulgarians killed the large garrison and a huge number of civilians. In his Chronography Theophanes pointed out:

whyle the army of the Strymon was receiving its pay, the Bulgarians fell upon it and seized 1100 lbs., of gold. They slaughtered many men together with their strategos and officers. Many garrison commanders of the other themata were present and all of them perished there [...] Before Easter of the same year, Kroummos, the leader of the Bulgarians, drew up his forces against Serdica, which he took by a deceitful capitulation and slaughtered 6000 Roman soldiers, not counting the multitude of civilians ${ }^{19}$.

The written monuments, however, also stressed upon the pogroms that the Byzantines caused in Pliska. Even taking into account the exaggerated scale, the actions of Emperor Nicephorus I north of Haemus Mountains caused revanchist attitudes at Krum's camp, too, and they do not imply a favorable treatment to the ones having been trapped in Bulgarian captivity ${ }^{20}$. Here, however, it looks as though the religious differences with the enemy are not the main driving force and there should be given what is needed for the desire for revenge. Such a moment has its mass executions committed by order of Khan Krum after the unsuccessful, perfidious

he entered in full armour together with his army to the acclamations of the demes, dragging the Bulgarian captives in wooden fetters. The latter he ordered to be beheaded by the citizens outside the Golden Gate - Theophanes, p. 599; As for the Bulgarian Huns, the following events took place. Coming to an agreement among themselves, they killed their hereditary lords and appointed as their ruler one called Telessios, a haughty man who yet exhibited the rashness of youth. This man gathered a band of armed fighters and overran vigorously the Roman villages that were nearest to him. On seeing his insolent boldness, Constantine built as many as eight hundred horse-carrying ships and, after loading them with a force cavalry, sent them by way of the Euxine to the Istros. He himself came to the city of Anchialos with another army. Telessios marched out against him with a grear multitude of Sclavonian allies but was defeated in battle and fled. Many of the bellingerents fell on both sides, and a considerable number of prominent men were captured. Having thus won the war, Constantine returned to Byzantium and delivered to the citizens and to the members of the so-called "colors" the captives he had brought along so that they would kill them with their own hands. Taking them outside the wall that lies on the landward side, they slew them - NikepHoros, p. 149, 151.

${ }^{19}$ Theophanes, p. 665.

${ }^{20}$ Theophanis Confessoris Chronographia, p. 282; Narratio anonyma e codice Vaticano, [in:] FGHB, vol. IV, p. 13. 
experience with a proposal for negotiations to lure him into an ambush and kill him ${ }^{21}$.

The situation is different when the captured imperial subjects, be it military or civilian, have been subjected to torture or were executed away from the battlefield and after a fairly long chronological span since the date of the battle. Such actions are not an exception. According to the notices of the final parts of the so-called Chronicle of 811, after the cessation of military actions Bulgarians try to force the Byzantine captives to renounce their Christian faith:

Many of the surviving Romans, after the battle ended, were forced by the impious Bulgars,

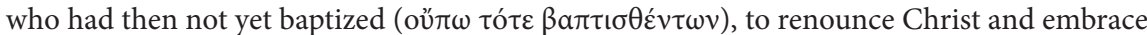
the error of the Scythian pagans. Those who were preserved by the power of Christ endured every outrage and by various torments earned the martyr's crown ${ }^{22}$.

Similar shades are presented in a service written by Joseph the Studite; in Book V of Theophanes Continuatus (Vita Basilii), whose author is considered to be Emperor Constantine VII Porphyrogenitus; in the story of the Synaxarium of the Church of Constantinople and in Menologion of Emperor Basil II. There is a clear idea to give a religious color to the repression of the Byzantine captives. This is the main unifying feature in notices; along with it, however, there is a chronological discrepancy. Theophanes Continuatus is about Khan Omurtag, which corresponds with the terms of the peace treaty between Bulgaria and Byzantium since 816. The Menologion marked repressions during the reign of Khan Krum and his successor Tsok (?!) and the story in the Synaxarium raises additional issues with the mentioning of Dukum and Ditsevg, describing them as those who took power over the Bulgarians before Khan Omurtag (815-831) ${ }^{23}$. The differences are at the basis of the hypothesis that the captives who are Christians undertake futile attempts to leave Bulgaria in an organized way even before 837/838 - during the time of Emperor Leo V (814-820). Within the Empire people learn about these efforts at a later stage through scattered second-hand information, and during recording and integrating these updates, a martyr-like feeling is attributed to them ${ }^{24}$. In this regard, it should be noted that despite the strong anti-Bulgarian position in the Theophanes' Chronography passages, relating to the events of 808-813/814 or Scriptor

\footnotetext{
${ }^{21}$ Scriptoris incerti historia..., p. 20-22.

${ }^{22}$ P. Stephenson, "About the emperor Nicephorus and how he leaves his bones in Bulgaria": A context for the Controversial Chronicle of 811, DOP 60, 2006, p. 90 (cf. Naratio anonyma e codice Vaticano, p. 14).

${ }^{23}$ Theophanis Continuati Chronographia, p. 118-119; Sinaxarium ecclesiae Constantinopolitanae, [in:] FGHB, vol. V, p. 288.

${ }^{24}$ Cf. Б. НиколовА, Неназован..., p. 63-76; Ф. Филипу, По въпроса за гонението на християни по време на управлението на кан Омуртаг, [in:] Оттука започва България. Материали от Втората национална конференция по история, археология и културен туризбм «Пттуване към Бблгария», Шумен, 14-16 май 2010, еd. В. Гюзелев, Шумен 2011, p. 178-182.
} 
Incertus de Leone Armenio, an aspect of torture and executions, dictated by a religious antagonism does not stand out in the same way. It is their clues that discourage the feeling of violence due to religious hatred ${ }^{25}$.

What has been mentioned is not intended to completely deny the cases of illtreatment and executions. Quite the contrary, the crude nature of the BulgarianByzantine conflict from 808 till 814 is out of the question. Furthermore, the threat to life and dignity covers a wide range of fighters and abducted civilians that are found to be in Bulgarian captivity, and the ethnic and religious differences further melt away the inhibitions. In fact, the words of Stephen Morillo about the fate of the ones fallen into enemy hands in conflicts between adjacent but different in political, ethnic and religious-cultural way societies, with some reservations about specific Bulgarian-Byzantine clashes since the middle $8^{\text {th }}$ till the middle of the $9^{\text {th }}$ century, are quite illustrative. He emphasized that

both sides fundamentally misunderstand each other in basic ways, failing to comprehend the goals, motivations and methods of their enemy. The opponents in intercultural warfare therefore often think themselves engaged in warfare with non-humans, variously conceived of as savage sub-human barbarians [...] Uncertainty and incomprehension also undermine conventions for the treatment of prisoners and non-combatants in intercultural war. Sometimes, the stresses of battlefield uncertainty found an outlet in excessive brutality towards non-combatants [...] Similarly brutal but far more calculated was the use of terror tactics - the slaughtering of entire urban population or villages to discourage future resistance ${ }^{26}$.

Certainly a practice of execution was facilitated by the religious differences between the enemies. However, cruelty and desire to slaughter a captured rival are well witnessed even after 865 when religious diversity between subjects of the Byzantine Empire and Bulgaria disappeared. Sometimes both sides still killed prisoners of war. And that feature continued to exist to the very end of the First Bulgarian state. Examples can be found in John Scylitzes' chronicle. For one of the struggles in 1016 the mentioned author wrote:

The situation around Dyrrachion then became very disturbed and distressed because John [Tzar John Ladislas (1015-1018) - Y.M.H.] repeatedly attempted to take the city, often by sending his commanders, sometimes coming in person. This is why the emperor [Basil II

${ }^{25}$ Theophanis Confessoris Chronographia, p. 280-283, 287-289; Scriptoris incerti historia..., p. 18-19, 20-22. Also: P. Stephenson, "About the emperor Nikephoros..., p. 90-109; P. Sophoulis, "The Chronicle of 811", the Scriptor incertus and the Byzantine-Bulgar wars in the early ninth century, BMd 1, 2010, p. 377-384.

${ }^{26}$ S. Morillo, A General Typology of Transcultural Wars - The Early Middle Ages and Beyond, [in:] Transcultural Wars from the Middle Ages to the $21^{\text {st }}$ Century, ed. Н.-H. КовтÜм, Berlin 2006, p. 34-35; Also: Ц. СтеПАнов, Периферията като вселена, [in:] История на българите: Потребност от нов подход. Преоценки, vol. I, еd. ІDЕм, София 1998, р. 107-121; IDEм, The Bulgars and the Steppe Empire in the Early Middle Ages: the Problem of the Others, Leiden-Boston 2010, p. $23-25,77-82$. 
- the Bulgarslayer - Y.M.H.] wished to go there and render aid, but for a reason worth noting he was prevented from doing so. When he was leaving for Ohrid, he left behind the commander George Gonitziates and the protospatharios Orestes 'the prisoner' with numerous troops and orders to overrun the Pelagonian plain. But they were taken in an ambush by the Bulgars under the illustrious and experienced command of Ibatzes and all killed $[\ldots]^{27}$.

A desire for revenge in the cited situation should be borne in mind, because just two years earlier thousands of captured Bulgarian warriors were blinded by Emperor Basil II. Even though there is no desire to justify them, it should be noted that the cases of killing large groups of Byzantine prisoners of war are dictated through purely tactical considerations - in the course of military actions. This includes a significant number of specifics: the distance between the place of the victorious battle and the difficult terrain to the Bulgarian territories; inability to protect and transport the captured enemies; problems with feeding and having too many people in need of medical care; low number of the winner, the possibility of a counterattack of other enemy compounds; after winning there is the need to advance in depth or to transfer the parts into another direction and so on ${ }^{28}$.

Nonmerciful attitude toward captives in Early Medieval Bulgaria was not limited to murders only. There were examples of torture, massmutilation and even sexual abuse. Among the more clearly visible notices of mass mutilations in the available sources are clues relating to the Bulgarian-Byzantine War of 894-896 - one of the early tests of Knyaz Symeon (Tzar since 913) who quite recently started sitting on the throne. The reasons for the outbreak of war and its development are well known ${ }^{29}$. The conflict between Bulgaria and the Empire is due to moving the market of Bulgarian goods from Constantinople to Thessalonica. Attempts for a diplomatic solution were unsuccessful and the armed confrontation becomes inevitable. Even in the early stages of the war of 894-896, the Bulgarian troops invaded a foreign territory and defeated the army sent against them. Then they won an important battle, but the war became tightened when the Byzantine side attracted the Magyars who at that time were located between the Dnieper and Dniester rivers. The turning point was when Knyaz Symeon allied with the eastern neighbors of the Magyars - Pechenegs and together they counterattacked their settlements along the Northern Black Sea Coast. The actions of the Bulgarian ruler are reflected in the Byzantine chronicles of the $10^{\text {th }}-11^{\text {th }}$ century. They note that

\footnotetext{
${ }^{27}$ JoHn SKYlitZes, p. 335

${ }^{28}$ In this regard, Christian charity and the comfortable proclaimed philanthropy of emperors are not obstacles before such actions by the Byzantines. Arab-Byzantine wars (far better represented by medieval writers) offered many evidences of massexecutions. Cf. A.M.A. RAMADĀN, The Treatment of Arab Prisoners of War in Byzantium, $9^{\text {th }}-10^{\text {th }}$ Centuries, AIs 43, 2009, p. 155-194 (157-159 in particular).

${ }^{29}$ Recently: M.J. LeszKa, The Monk versus the Philosopher: From the History of the Bulgarian-Byzantine War 894-896, SCer 1, 2011, p. 55-70.
} 
in the battle in 894 the victims of the Byzantine side are many, not only from the chiefs, but from the lower ranks as well. At the same time, many prisoners fall into Bulgarian hands, and faithful to the old tried and tested practices of the pagan era of the Themes of Thrace and Macedonia, the Bulgarian ruler ordered the kidnapping of civilians as well ${ }^{30}$. There were slaughterous Bulgarian victories in previous decades, but in 894 a new aspect emerges in Symeon's action. With noses cut off the Khazar members of Heteria (Imperial Guard) were sent to Constantinople. Amid the ensuing battles that mutilation of prisoners of war appears to be left behind. Chroniclers agree that the act of the Bulgarian ruler is the reason Emperor Leo VI (886-912) to ally with the Magyars and continue the conflict ${ }^{31}$. Attempts to explain the motives of Bulgarians and Byzantines gravitate around the idea of revenge or permanently formed anti-Khazar moods of Bulgarians. The erosion of such an explanation comes with already offered various research solutions. They help in taking into account characteristics in public and court ceremonial in Constantinople and functioning symbols, actions and gestures that demonstrate the real attitude of the ruling circles to the metropolitan population. As a Constantinople graduate, the recently ascended to the Bulgarian throne Symeon was aware that the ostentatious return of mutilated representatives of the military unit directly connected with the imperial personage would personally humiliate Emperor Leo VI. This in turn explains the anger of the latter one, his determination to find an ally and to continue the war with the Bulgarians, and why the Byzantine authors describing the events, speak of shame, disgrace to the Byzantines and insult ${ }^{32}$.

Especially appreciated among Barbarian societies in Early Medieval Europe group of captives are the women and to some extent children. It is they who often remain without protection, only at the mercy of the winner after the killing of men $^{33}$. In practically devoid of moral and ethical-religious inhibitions conflicts with the Empire before the conversion of Medieval Bulgaria, women and

\footnotetext{
${ }^{30}$ Leonis Choerosphactis Epistolae, p. 176-180, 182.

${ }^{31}$ Theophanis Continuati Chronographia, p. 121-123; Leonis Gramatici Chronographia, p. 158-159; Georgius Monachus Continuatus, p. 138-140; Symeonis Magistri et Logothetae, p. 275, 82-276, 116; Ioannis Scylitzae Synopsis, p. 175, 75-177, 19.

32 Л. Симеонова, Семиотика на унижението: Високопоставени чужденци в имперската стотица през Х век, Род 4, 1996, p. 39-40; ЕADEм, Разшифроване на езика на символите..., p. 13-18; EADEM, Foreigners in Tenth-Century Byzantium: A Contribution to the History of Cultural Encounter, [in:] Strangers to Themselves: The Byzantine Outsider. Papers from the Thirty-second Spring Symposium of Byzantine Studies, University of Sussex, Brighton, March 1998, ed. D.C. Smythe, Aldershot 2000 [= SPBS.P, 8], p. 229-244; П. ПАвлов, Българо-хазарски взаимоотночения и паралели, [in:] Българи и хазари през ранното средновековие, еd. Ц. СтеПАнов, София 2003, p. 131.

${ }^{33}$ C. Sounders, Sexual Violence in Wars - The Middle Ages, [in:] Transcultural Wars..., 151-163; J. Gillingham, Women, Children and the Profits of War, [in:] Gender and Historiography. Studies in the Earlier Middle ages in Honour of Pailine Stafford, ed. J.L. Nelson, S. Reynolds, S.M. Johns, London 2012, p. 61-74.
} 
children undoubtedly fall within the scope of enemy troops. This is captured by the division of captives non-combatants by gender and partly on the ground of age ${ }^{34}$. Beyond that, in narratives strokes of their fate are much more subtle. This is due to peculiarities in the narration of Byzantine authors of $9^{\text {th }}-10^{\text {th }}$ century. This largely explains why there are missing passages on the treatment of the non-combatants by Bulgarian armies such as those in Procopius of Caesarea, talking about invasions of Slavic plunderers in the imperial provinces, he noted the killing of men capable of carrying weapons and kidnapping of women and children north of the Danube by adding particularly detailed descriptions of impalement, beating, mutilation or burning prisoners alive ${ }^{35}$. No less eloquent is Agathias's description on the attack of the Kutrigur ruler Zabergan in Eastern Thrace, in which the sexual abuse of young women and girls, including nuns, is accompanied by being left at the mercy of fats and infants were preys to wild animals ${ }^{36}$. Exactly this kind of details look as if they were skipped in the texts providing information about what was happening with the captives by Bulgarians in $8^{\text {th }}-10^{\text {th }}$ century. In the interest of objectivity it is necessary to acknowledge that the lack (to my knowledge) of passages about the fate of the Byzantine captives among Bulgarians as harsh as those in Procopius and Agathias, including the works of Patriarch Nicephorus, Theophanes Confessor, George Hamartolus, Theophanes Continuatus, may be due to the lack of similar events by participants in Bulgarian trips abroad. However, a doubt still lurks and the reason is that the absence of evidence is famously not evidence of absence, as John Gillingham pointed out in an attempt to overcome the condition of some poorly documented features of captives' lives in medieval Western Europe ${ }^{37}$. By conditionality and considerable caution, a key towards partially overcoming the shortage of direct information is provided by fragments of the chronicles of Scriptor incertus, Joseph Genesius and Theophanes Continuatus. The first of these mentions that the troops of Khan Krum move towards the European part of today's Turkey after their withdrawal from Constantinople in 813. On the Ganos Mountains [hills in Eastern Thrace, near the Sea of Marmara] the army of the Bulgarian Khan comes across

\footnotetext{
${ }^{34}$ Scriptoris incerti historia..., p. 21-23; Leonis Gramatici Chronographia, p. 156; Pseudo-Symeonis Chronographia, p. 171-172; ПрОДОЛЖАТЕЛЬ ФЕОФАНА, p. 142-143.

${ }^{35}$ Procopius, History of the Wars, vol. V, ed. et trans. H.B. Dewing, London-Cambridge Mass. 1962, p. 23-27.

${ }^{36}$ Agathias, The Histories, ed. et trans. J.D. Frendo, Berlin 1975, p. 148. One should be reminded that Byzantine chroniclers described some tortures, albeit in connection with another moment - a widescale internal war in 821-823 known as the revolt of Thomas the Slav. For example: ПродолжАтель Феофана, p. 49-50; Genesios, On the Reigns of the Emperos, ed. et trans. A. Kaldellis, Canberra 1998 [= BAus, 11; cetera: GeNESIOs], p. 38-39.

${ }^{37}$ J. Gillingham, Christian Warriors and the Enslavement of Fellow Christians, [in:] Chevalerie et Christianisme aux XII e et XIII siècles, ed. M. Aurell, G. GirbeA, Rennes 2011, p. 237-255.
} 
many people and almost all animals of Thrace. They slaughtered the men, and the cattle that was a great multitude, was captured and sent to Bulgaria, along with a large number of women and children ${ }^{38}$.

The same historical source points out a noticeable difference with the abducted and deported people from Arcadiopolis and its vicinity in the spring of 814. All captives - men, women and children without exception, with all their movable property and livestock, were taken to Bulgaria ${ }^{39}$.

In the actions of Emperor Leo V against the Bulgarian compounds near Mesembria in 815 in chronicle of Theophanes Continuatus, and in the work of Joseph Genesius, it is said that after the victorious battle the Byzantines indulge in cruelties. Genesius even notes that this is an act of retribution for what Bulgarians cause to the imperial subjects. According to the text, the victims are of all ages, explicitly stating that among them there are children, too ${ }^{40}$. Another brutal manifestation of the principle of do to others what they have done to you in the Bulgarian-Byzantine War of 807-815 is not ruled out at all. Especially if one considers that after the capture of Mesembria in 812 Bulgarian soldiers and their families are transferred in the city, and there are Slavs settled in close vicinity ${ }^{41}$. However, it should also be taken into account that when a Christian chronicler of the Late Antiquity or the Middle Ages mentions in his work children who were dashed against the rocks, may involve a topos, which was based on Psalm 136, $9^{42}$.

There is some indication of mistreatment and probably sexual abuse over captives in Early Medieval Bulgaria and the difficult situation in which teenagers find themselves after the killing of their parents. It must be recognized, however, that it does not provide the so coveted by researchers details. It rather indicates that actions clearly marked with Slavic displacements on the Balkans and the raids of nomadic groups in the north of the Black Sea Coast in the early Byzantine era are repeated by some members of the Bulgarian corps operating on an enemy territory at a later stage as well. Such a feeling is created by the correspondence of Patriarch Nicholas I Mysticus (901-907, 912-925). In a relatively common phrase

\footnotetext{
${ }^{38}$ Scriptoris incerti historia..., p. 22.

${ }^{39}$ Ibidem, p. 23.

${ }^{40}$ ПрОДОЛЖАТЕЛЬ ФЕОФАНА, p. 21; GeNesios, p. 13-14.

${ }^{41}$ К. Станев, Тракия..., p. 116-120.

${ }^{42}$ In fact, biblical references are exploited by the Byzantine authors in search of a justification corresponding to the Christian concepts for the cruelties and bloodshed caused by the imperial armies during the war. J. Haldon, Warfare, State and Society in the Byzantine World, 565-1204, London 1999, p. 13-33; W. Treadgold, Byzantium, the Reluctant Warrior, [in:] Noble Ideals and Bloody Realities: Warfare in the Middle Ages, ed. N. Christie, M. YAZIGI, Leiden-Boston 2006, p. 209-233; J. Koder, I. Stouraitis, Byzantine Approaches to Warfare ( $6^{\text {th }}-12^{\text {th }}$ centuries). An Introduction, [in:] Byzantine war ideology between Roman imperial concept and Christian religion, ed. IIDEM, Vienna 2012, p. 9-15; I. Stouraitis, 'Just War'and 'Holy War' in the Middle Ages. Rethinking Theory through the Byzantine Case-Study, JÖB 62, 2012, p. 227-264.
} 
the senior Byzantine cleric accused the Bulgarian Tzar Symeon of economic ruin, orphaned children, merciless attitudes, murders and throwing away of women's corpses in connection with the new peak of Bulgarian-Byzantine opposition from the beginning of the tenth century ${ }^{43}$.

Massacres, abuses, tortures and blind brutality are not the only option. Other measures are not excluded. Although it sounds modern, the most applicable term describing the efforts is integration. Furthermore, the entry in the military-political and economic structures of the Early Medieval Bulgaria can be a group one as well as an individual one. It must be noticed that most of the battle winners could hardly resist to integrated and incorporated civilian captives and defeated troops into their own society, regardless whether peacefully or by force. Such measures diminished rival's resources and increased their own economic and military power.

One of the earliest manifestations of an attempt to settle a compact group of captives in pagan Bulgaria is registered in Theophanes' Chronography. In connection with the efforts of Khan Telerig (768-777) in 773/774 to organize a transfer of the Berziti dwelling in area of present-day Kičevo, Prilep, Bitola and Veles, the text notes:

In the month of October of the $11^{\text {th }}$ indiction the emperor [Constantine V - Y.M.H.] received a dispatch from his secret friends in Bulgaria to the effect that the lord of Bulgaria was sending an army of 12000 and a number of boyars in order to capture Berzitia and transfer its inhabitants to Bulgaria [...] [Constantine V - Y.M.H.] gathered the soldiers of the themata and the Thrakesians and joined Optimati to the tagmata to a total of 80000 . He marched to a place called Lithosoria and, without sounding the bugles, fell upon the Bulgarians, whom he routed in a great victory. He returned with much booty and many captives and celebrated a triumph in the City, which he entered with due ceremony. He called this war a 'noble war' inasmuch as he had met with no resistance and there had been no slaughter or shedding of Christian blood ${ }^{44}$.

Reservations to what the Byzantine chronicler says that Khan Telerig wanted to capture the Slavic group of Berziti and forcefully to deport them to Bulgaria are voiced by Bulgarian medievalists a century ago - at the beginning of the $20^{\text {th }}$ century. However, some doubts remain. Even with the preliminary arrangements made between Khan Telerig and the knyazes of Berziti, there is still an inquiry why a voluntary migration in Bulgaria needs organizing a military expedition whose success strongly depends on keeping it a secret ${ }^{45}$.

\footnotetext{
${ }^{43}$ Nicholas I Patriarch of Constantinople, Letters, Greek text and English translation, ed., R.J.H. Jenkins, L.G. Westernik, Washington 1973 (cetera: Nicholas I, Letters). Letters from Patriarch Nicholas I to Archbishop of Bulgaria and to Tzar Symeon: № 12, p. 89; N 14, p. 97. (cf. Nicolai Constantinopolitani Archiepiscopi Epistolae, [in:] FGHB, vol. IV, p. 227, 231).

${ }^{44}$ Theophanes, p. 617.

${ }^{45}$ В. ЗлАТАРсКИ, История на българска държава през средните векове, vol. I, pars 1, Епоха на хуно-българското надмощие (679-852), София 1918, р. 302-303. Сf. Живковић, Јужни словени
} 
For various reasons, the appeal of the barbaric way of life and conditions for development, achieving a social status or just the need for salvation is the reason for imperial subjects to integrate successfully in pagan Bulgaria. An announcement for such an outlined feature at the beginning of the $9^{\text {th }}$ century is given by Theophanes Confessor right in the narrative about capturing Christijan - the leader of Skamari in 764 by the people of Emperor Constantine $\mathrm{V}^{46}$. A significant part of the stored evidence for this particular group of Byzantines, even when it comes to those who were part of the Imperial Army, does not give grounds for them to be designated as prisoners of war, even in the broader context of medieval conceptions. Robert Browning qualified those persons with the milder term immigrant in order to avoid the deserter and traitor ${ }^{47}$. The military, administrative and political cooperation with the pagan Bulgarian elite is clear ${ }^{48}$. Judging by notices of John Scylitzes, there are escapes of imperial subjects and military men in Bulgaria at a much later stage, too.

\begin{abstract}
It was at that time that two men were accused of being sympathetic to the Bulgars: the magister Paul Bobos, one of the leading citizens of Thessalonike, and Malakenos, distinguished by his intelligence and eloquence [reported the mentioned chronicler - Y.M.H.] Paul was transferred to the plain of the Thrakesion, Malakenos to Byzantium. Certain distinguished citizens of Adrianople who had also gained renown in military commands fled to Samuel because they were under suspicion: Vatatzes with his entire family, Basil Glabas alone $[\ldots]^{49}$.
\end{abstract}

The example of Constantine Patzik - married to the sister of Khan Krum suggests that one of the ways for the integration of immigrants and defectors with specific skills or a high rank is through intermarriages ${ }^{50}$. Without ignoring the romantic moment, the marriages of Miroslava and Theodora-Kosara - daughters of Tzar Samuel, respectively for Ashot Taronites and Dioclean knyaz John Vladimir is a clear indication that the practice is applied to real prisoners of war $^{51}$. However, at elite level, the desire for integration through marriage in the Bulgarian society definitely has additional shades. For example, according to reports of Emperor Constantine VII Porphyrogenitus, however, the successfully ruling Serbian Prince

под византијском власћу 600-1025, Београд 2007, p. 140-141; F. CURTA, Were There any Slavs in Seventh-Century Macedonia?, Исто 47.1, 2012, p. 61-74.

${ }^{46}$ Theophanis Confessoris Chronographia, p. 272.

${ }^{47}$ R. Browning, Byzantines in Bulgaria, late $8^{\text {th }}$ - early $9^{\text {th }}$ Centuries, [in:] Studia Slavico-Byzantina et Mediaevalia Europensia. In memoriam Ivan Dujčev, vol. I, ed. P. Dinekov et al., Sofia 1988, p. 32-36. ${ }^{48}$ Р. РАшев, Византийците в Бблгария..., р. 152, 155-158.

${ }^{49}$ John SKylitzes, p. 325.

${ }^{50}$ Scriptoris incerti historia..., p. 20-21.

${ }^{51}$ Ioannis Scylitzae Synopsis, p. 341, 13-22; p. 342, 52-57; Добавки на епископ Михаил Деволски от 1118 г. към „Исторически свод” на Йоан Скилица (XIв.), [in:] Извори за средновековната история на България (VII-XV в.) в Австрийските ръкописни сбирки и архиви, vol. I, ed. В. ГюзЕлев, София 1994, p. 53; Annales anonymi presbyteri de Dioclea, [in:] FLHB, vol. III, p. 174. 
Petar Gojniković lives his life as a Bulgarian captive. The same fate seems to have been assigned to John Haldus the Duke of Thessalonica who spent two decades in captivity and was released only after the conquest of the First Bulgarian state by Byzantium $^{52}$.

There are far more numerous group attempts to integrate the captured in Thrace imperial subjects in the second and third decade of the $9^{\text {th }}$ century. Several Byzantine chronicles tell of their settlement on the eastern periphery of Bulgaria beyond the Danube River ${ }^{53}$. Based on the clues, their preserved religious and cultural otherness in comparison with the rest of the pagan population of Bulgaria is not subjected to doubt. This stored identity is cited as a major reason for their integration attempt in the border structures of the Bulgarian state in 820s-830s to ultimately fail. Contacts with the imperial ruling circles, the revolt in 837 , at the very beginning of the rule of Khan Presian (836-852) and obviously the well-planned and carried out evacuation with the help of the Byzantine fleet are serious grounds to support such a claim. However, perhaps there are additional considerations as their otherness is visible and strongly reported by the Bulgarian ruling elite during the rule of khans Omurtag and his successor Malamir. Religious and ethno-cultural differences did not undermine the loyalty of immigrants for 20 years, during which they played the role of armed frontier populations with their commanders, and in their settlements in Bulgaria beyond the Danube River the next generation was born and grew up ${ }^{54}$.

Looking at the policies towards prisoners of war in pagan Bulgaria it is reasonable to pay attention to the preserved information in the article Bulgari

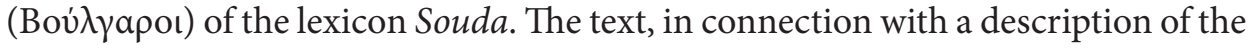
legislative activities of Khan Krum, generally talks about Avar captives ${ }^{55}$. No clues suggest who knows what detailed comments and it seems logical and really likely, after the expansion against the remnants of the Khaganate during the rule of the mentioned ruler, that Avar captives might have fallen into Bulgarian hands. Significantly, in the statement drawn up in the second half of the tenth century Souda does not find any support in the text closer to the events in time - Chronicle of 811

\footnotetext{
${ }^{52}$ DAI 32, 95-99; Ioannis Scylitzae Synopsis, p. 357, 73-75.

${ }^{53}$ Scriptoris incerti historia..., p. 22-24; Georgii Monachi Chronikon, p. 56; Georgius Monachus Continuatus, p. 135-137; Leonis Gramatici Chronographia, p. 156; Pseudo-Symeonis Chronographia, p. 172-173; Ioannis Scylitzae Synopsis, p. 116, 5 - 118, 48.

${ }^{54}$ I. Mladjov, Trans-Danubian Bulgaria: Reality or Fiction, ByzS 3, 1998, p. 86-87, 89-90, 95-96; К. Станев, Депортираните ромеи..., p. 185-189; Among the possible reasons is exactly the appearance of the Magyars and in their immediate neighborhood - the Petchenegs in the western periphery of the Khazar Khaganate. I. BožILov, One of Omourtag's Memorial Inscriptions, BHR 1, 1973, р. 72-76; Г. АтАнасов, Българо-хазарската граница и българо-хазарската враждебност от края на VII до средата на IX век, [in:] Българи и хазари през ранното средновековие, еd. Ц. СТеПАнов, София 2003 [= ББВ, 43], p. 108-110.

${ }^{55}$ Suidae Lexicon, [in:] FGHB, vol. V, p. 310.
} 
and Scriptor incertus. Two narratives' data present Bulgarian-Avars relation in very obscure scratches. However, it is clear that Avars took a part in the army collected by Khan Krum and were among the troops which assaulted Byzantine forces in Haemus mountains. In the Chronicle of 811 it is specified that Avars auxiliary recruits before the battle of July 26,811 were attracted by the payment. In addition, the author of Scriptor incertus also mirrored that Bulgarian ruler who prepared attack on Constantinople got military assistance of the Avars reinforcements again. Despite this fact there is no word about an execution of some submissive captives' obligations ${ }^{56}$. In this regard, groups acknowledging the supremacy of the Bulgarian khanate after the collapse of the Avar khaganate in the first decade - a decade and a half of the $9^{\text {th }}$ century - have a more federal status and in the search for stability and preservation of positions the Carpathian Basin are being in a process of an aware and relatively voluntary entry into the growing power of the Bulgarian state. For the members of Avar elite, as Panos Sophoulis pointed out, this process was facilitated by the common lifestyle (i.e. the semi nomadic economy and the social institutions it creates), the consciousness of a shared past, true or false, and a strong politico-military leadership, and most probably also by the Bulgarian policy toward the Mid-Danubian Slavs ${ }^{57}$.

A larger group of captives who are not imperial subjects falls into Bulgarian hands at the beginning of the tenth century. After the failure of the imperial armies in open battles with Symeon's troops, the ruling circles in Constantinople are forced to seek allies. This diplomatic activity gives good results in the Serbian principality with a centre east of Dinaric Mountains. In fact, the choice of an antiBulgarian ally is not accidental. According to the notices of Emperor Constantine VII Porphyrogenitus in Chapter 32 of De Administrando Imperio, in the $9^{\text {th }}$ century Serbs have the experience of two successful wars - Knyaz Vlastimir against Khan Presian and Knyazes Mutimir, Stoimir and Goynik Vlastimirovič against Knyaz Boris-Michael ${ }^{58}$. At the end of the first quarter of the tenth century the successes of the Byzantine diplomacy in attracting Knyaz Paul - son of Bran and grandson of Knyaz Mutimir, and later Knyaz Zacharias (923-924) - son of Knyaz Pribislav, Mutimir's eldest son, lead to an outbreak of a new Bulgarian-Serbian war. Two marches were organized against the Serbian possessions. What happens to ordinary soldiers after the defeat in the first march in $D A I$ was not reported,

\footnotetext{
${ }^{56}$ Naratio anonyma e codice Vaticano, p. 13; Scriptoris incerti historia..., p. 23.

${ }^{57}$ P. Sophoulis, New Remarks on the History of Byzantine-Bulgar Relations in the Late Eighth and Early Ninth Centuries, Bsl 67.1/2, 2009, p. 135-136; P. Komatina, The Slavs of the Mid-Danube Basin and the Bulgarian Expansion in the First half of the $9^{\text {th }}$ century, ЗРВИ 47, 2010, p. 55-82; H. GRAČANIN, Bulgari, Franci i Južna Panonija u 9. stoljeću. Reinterpretacija povijesnish izvora, [in:] Hrvati i Bugari kroz stoljeća. Povijest, kultura, umetnost i jezik. Zbornik radova sa znanstvenog skupa održanog u Zagrebu i Đakovu, 23-24 rujna 2010, ed. D. KARBIĆ, T. Luetić, Zagreb 2013, p. 3-22.

${ }^{58} \mathrm{DAI}, 32,38-49$.
} 
but there is some clarity for the commanders. The two Bulgarian noblemen who also commanded previous initiatives in the Serbian lands - Marmais and Theodore Sigritza were killed and their heads and weapons were sent as trophies to Emperor Romanus I Lecapenus (920-944) ${ }^{59}$. The cruelty shown by Knyaz Zacharias Pribislavič proves counterproductive. Tzar Symeon abandons the idea to change one protégé with another one on the Serbian throne, and proceeded with conquering the principality. Just in terms of conquest, as it is noticed, solutions are applied, which are not only related to aristocrats being prisoners of war, but they also have a mass character. The descriptions of Emperor Constantine VII Porphyrogenitus are not so detailed, but the main points stand out:

\footnotetext{
Again, Symeon sent another army against Prince Zacharias, under Kninos and Himnikos and Itzboklias, and together with them he sent also Tzeëslav. Then Zacharias took fright and fled to Croatia, and the Bulgarians sent a message to the 'zupans' that they should come to them and should receive Tzeëslav for their prince; and having tricked them by an oath and brought them out as far as the first village, they instantly bound them, and entered Serbia and took away with them the entire folk, both old and young, and carried them into Bulgaria, though a few escaped away and entered Croatia; and the country was left deserted ${ }^{60}$.
}

The manifested doubt on the claim that the Serbian principality with a centre east of the Dinaric Mountains is really being abandoned is at least reasonable. At the same time, it should be recognized that Tzar Symeon in his campaigns also proceeded to capture and deport large populations ${ }^{61}$. In this sense, though with undoubted and at places too serious bias in the DAI text, it seems logical that in 924 Knyaz Zacharias does not wait for a fighting and frightened he flees to Croatia, while the zupans are gathered and shackled, then there is a mass capture and kidnapping of people in Bulgaria in the conquest of Serbian lands. The restoration of the Serbian principality, its re-settlement and the gradual return of the population began seven years after Symeon's punitive expedition. This happens under the changed conditions in the Bulgarian-Byzantine relations in 930s and the need of a buffer against the Magyars on the Middle Danube ${ }^{62}$.

Sticking to the tried and tested practices against captured members of the political elite and mass deportations and integration efforts of the abducted by a foreign territory population is also present in the last years of the existence of the First Bulgarian state.

\footnotetext{
${ }^{59}$ Ibidem, 32, 99-116.

${ }^{60}$ Ibidem, p. 159.

${ }^{61}$ Leonis Choerosphactis Epistolae, p. 176-182; Nicolai Constantinopolitani Archiepiscopi Epistolae, p. 256-257; Romani Lacapeni Epistolae, [in:] FGHB, vol. IV, p. 300-313; Theophanis Continuati Chronographia, p. 122-123; Leonis Gramatici Chronographia, p. 158-159; Pseudo-Symeonis Chronographia, p. 176, 179; Georgius Monachus Continuatus, p. 139-140.

${ }^{62} \mathrm{DAI}, 32,128-145$.
} 
Samuel became the sole ruler of all Bulgaria; he was much given to waging war and not at all possessing his soul in peace. When the Roman forces were occupied with the war against Sclerus he seized his chance and overran all the West, not only Thrace, Macedonia and the region adjacent to Thessalonica, but also Thessaly, Hellas and the Peloponnese [wrote John Scylitzes - Y.M.H.]. He also captured several fortresses of Larissa was the outstanding example. He transferred the inhabitants of Larissa, entire families of them, into further Bulgaria where he enrolled them among his own forces and used them as allies to fight against the Romans ${ }^{63}$.

Details about capturing the key Thessaly fortress of Larissa and the subsequent displacement in the Bulgarian state are given in the Strategikon of Cecaumenus ${ }^{64}$.

With some reservations, the next moment that is relevant to the issues outlined in the reign of Tzar Samuel (997-1014) is during his march on the Dalmatian coast. When using data from the chronicle of the anonymous author, named in scientific fields as The Priest of Diocleia problems should be taken into account regarding the identification, dating and reliability, as the text includes various local tales in quite a legendary type and unsaved Life after the glorification of the Dioclean Knyaz John Vladimir $(\dagger 1016)$ as a saint ${ }^{65}$. With the clear understanding of the questions about Chapters 36-37, it should be pointed out that there is stored information about the policy of Tzar Samuel towards prisoners of war. Some similarities stand out just in relation to the solutions applied in the First Bulgarian state, both for the elite group of aristocrats and senior military men and at the popular level. Fragments of the text are well-known. According to the anonymous author the young Dioclean Knyaz John Vladimir truly realized that he could not risk engaging in an open battle and withdrew with all his people on the top of Oblik Mountain in order to escape massacres. Blocked by Bulgarian forces, the young knyaz becomes the victim of a betrayal, and was sent to Bulgaria. This gives an opportunity for Tzar Samuel to regroup forces and to unfold the march in Dalmatia. Bulgarian army devastated, reduced to ashes and plundered both maritime and mountainous regions as far as Zadar. On the way back Samuel's troops passed through Bosnia and Rascia. The following passages in Chapter 36 of the Duklyan's chronicle, along falling in love and the marriage of Knyaz John Vladimir and Samuel's daughter Theodora-Kosara, present the situation with Diocleia and Trabounia after the Bulgarian march. After the wedding, Knyaz John Vladimir returned to his former possessions, but as a Bulgarian appointee, engaged with the policy of his father-inlaw. An additional engagement of the prince in the structures of Samuel's Bulgaria can also be considered the transfer of the whole territory of Dyrrachium under his rule ${ }^{66}$. If notifications are not fiction but have a historical basis, are based on

\footnotetext{
${ }^{63}$ John SKYLITZES, p. 312-313.

${ }^{64}$ Кекавмен, p. 265-268.

${ }^{65}$ Annales anonymi presbyteri de Dioclea, p. 173-179.

${ }^{66}$ Ibidem, p. 173-175.
} 
real events and processes, they have traces of solutions applied to prisoners of war in the First Bulgarian state. The anonymous author emphasized on the disaster which affected the Dalmatian coastline as well as the villages in the interior and the entire area was left uninhabited. It should not be omitted that according to the text Tzar Samuel notified the refugee Dragimir, Vladimir's uncle that he allowed him to come to the court in order to receive the land of Trabounia, where Dragimir might gather his people and settle the province ${ }^{67}$. Even with reservations around the scales, mentioning the scattered and abducted people and the resettlement of an uninhabited territory whose knyazes are either expatriates or prisoners of war in Bulgaria, finds a parallel in the descriptions in Chapter 32 of DAI of the conquered Serbian lands of Vlastimirovič dynasty of 924 - early 930s. The tempting additional comments seem as if it is best that they are skipped. Such a decision is not due to excessive academic caution. The reason is that the clichéd excuse about the source basis, which does not allow more substantial details relative to the specific part of the text of The Priest of Diocleia brings a general imperative.

Along with attempts to replenish its military, economic and demographic resources through the integration of captives, there are other factors that contribute to the safety of their lives. After the victory in the gorges of the Haemus Mountains on July 26, 811 there is the inability for Khan Krum to immediately begin an offensive against the Empire. It was mainly due to the need to regroup and at least an initial aftermath of the Byzantine penetration north of the mountain ${ }^{68}$. Along the mention of heavy losses in the Byzantine camp, there is not enough reliable indication of how trapped offside Byzantine soldiers survived and were taken into captivity. A part of the alleged prisoners of war is probably offered as a gift and compensation to Avar leaders and Slavic knyazes for their military cooperation. One group of all captives to the end of the conflict in 816, as noted, fills the need for manpower and is released only in the elderly age after years of heavy physical exercises for major construction endeavors in Pliska and the area around the capital ${ }^{69}$. One cannot deny that because of the insignificant worries of accidents during hard labor, or conditions of shelter, quality of the food offered, combined with the age of lower ranks in the army and their health and physical condition, the prisoners of war are particularly

\footnotetext{
${ }^{67}$ Ibidem, p. 175; С. ПиривАтрит, Дукља, Бугарска и Византија на Јужном Јадрану крајем 10. и почет-ком 11. века, [in:] България и Сърбия в контекста на византийската ичивилизация, ed. В. ГюЗЕЛЕВ, А. МиЛтенОвА, Р. СТАНКОвА, София 2005, р. 91-99.

${ }^{68}$ About the reasons for postponing the Bulgarian offensive in the spring of $812-$ И. Божилов, В. Гюзелев, История на България в 3 тома, vol. I, История на средновековна България VII-XIV век, София 1999, p. 130-132.

${ }^{69}$ К. СТАнев. Съдбата на ромейски войници..., р. 29-31.
} 
suitable for such an activity. Among the most important issues is the need for a strict and organized supervision to prevent escapes and riots ${ }^{70}$.

One should not overlook the fact that there are even far more explicit data about Byzantine prisoners of war being used as a bargaining chip and means of political pressure against the Empire in order to achieve more favorable conditions for peace. This practice concerns the prisoners of war of all kinds and variety. It is quite understandable. No medieval ruler could easily accept a serious loss of military power and taxpayers. So striving for redemption of one's own captured warriors is quite understandable. Aspects and forms of exchange and mutual concessions or even implicit obedience to the enemy in order to retrieve survived warriors, military commanders, are visible in the Bulgar-Byzantine Peace treaty of 816. Some of its provisions are preserved in Khan Omurtag's stone inscription of Suleimankoi (now the village of Sečište, northeastern Bulgaria). Its content is of chrestomathical fame. The passages relevant to the issue of captives in Early Medieval Bulgaria read:

\begin{abstract}
The third chapter is about the Slavs who live along the seacoast and are not ruled by the Emperor. He should send them back to their settlements. The fourth chapter is about the Christian prisoners of war and those captured [...] for the turmarchs, spatarii, and the comites. He will give $[\ldots]$ the rank and file will be a soul for a soul [a man for a man]. Two water buffalos will be given for those captured in a fortress, if $[\ldots]$ villages. If a strategos defected $[\ldots]^{71}$.
\end{abstract}

The damaged parts are consuming, but in the current state, the epigraphic monument unequivocally shows that ordinary soldiers are exchanged on a reciprocal basis - one person for another one. Along with the arrangements for the exchange of 1:1, apparently the captured Byzantines, even from the lower ranks and chiefs, are many more compared to those in the hands of the emperor - Bulgarian soldiers and captured civilian residents. This requires a number of additional commitments on Byzantine's behalf since the option a soul for a soul is not enough ${ }^{72}$.

\footnotetext{
${ }^{70}$ About such an option: [...] In the month of February two Christian refugees from Bulgaria [...] - Theophanes, p. 683. Also: [...] as some escaped captives from Bulgaria say, on Maundy Thursday before Easter, the first Bulgarian, the famous Krum, who had intended to take over the capital, ended his life [...] - Scriptoris incerti historia..., p. 24.

${ }^{71}$ K. Petкov, The Voices of Medieval Bulgaria, Seventh-Fifteenth Century. Records of a Bygone Culture, Leiden-Boston 2008 [= ECEEMA, 5], p. 7-8.

${ }^{72}$ В. БЕшевлиев, Първобългарски надписи..., p. 164-175. There is not much reason to doubt that commanders are exchanged via seniority and the ransom price is dependent on their rank. In conquering the strongholds, members of the higher levels in the church hierarchy fall into Bulgarian hands, too. Theophanis Confessoris Chronographia, p. 284, 286-289; Sinaxarium ecclesiae Constantinopolitanae, p. 287-288; Theophanis Continuati Chronographia, p. 119; Menologium Basilii, [in:] FGHB, vol. VI, p. 55. A comparison between the prices of cattle and harnessed animals to that of slaves in Byzantium, and other paid ransoms of the early Byzantine era to the first half of the $9^{\text {th }}$ century is also quite revealing - C. Morrisson, J.-C. Cheynet, Prices and Wages in the Byzantine World, [in:] The Economic History of Byzantium: From the Seventh through the Fifteenth Centuries, vol. II, ed. A. LAïou et al., Washington 2002, p. 839-850.
} 
The detention of a large group of prisoners of war and civilian abductees brings positives not only as a means to achieve favorable conditions for peace and extract economic benefits but also in adverse developments of the circumstances. Such a feeling is created by the Bulgarian-Byzantine War of 894-896. After the first battle won by the Bulgarians in Thrace, peaceful inhabitants are kidnapped and taken north of Haemus and they are held in captivity. The inclusion of Magyars on Byzantine's side in the war and the deep penetration of their squadrons in the Bulgarian lands placed Symeon, who recently took over, in a difficult situation. Byzantine allies defeated the Bulgarians, the ruler himself sought safety behind the walls of Drastar and Magyars sacked unprotected villages and took captives that Emperor Leo VI redeemed and transferred to Byzantium. The detention of the abducted residents from the Themes of Thrace and Macedonia in Bulgaria enables the Bulgarian ruler to make demands for his own captive subjects. According to the reports, the Bulgarian envoys particularly arrived in Constantinople to free them. Meanwhile, Magister Leo Choerosphactes is charged with the daunting mission to negotiate the return of the abducted Byzantines ${ }^{73}$.

In the first quarter of the tenth century Tzar Symeon continues to pose serious challenges to the ruling circles in Constantinople, using the Byzantine captives. Summarized they are given by the anonymous hagiographer, compiled the Life of St. Luke of Steiris.

Symeon, the Archon of the Scythian people we are usually accustomed to call Bulgarians violated the contract with the Romans, went over the whole land [...] [the text reads - Y.M.H.] he took captives and plundered, he deprived some of their lives, while others of freedom and they were made taxpayers ${ }^{74}$.

An additional shade appears registered in the letters of Emperor Romanus I Lecapenus to Tzar Symeon. The Bulgarian ruler was accused that the kidnapped imperial subjects were sold in slavery of unfaithful nations. Grounds for concern in the ruling elite of the Empire are to a large extent understandable. While warriors and civilians are in Bulgarian hands there is a possibility for them to be redeemed, exchanged or even to escape. Selling them as slaves outside Symeon's possessions creates additional difficulties ${ }^{75}$. The notice to engage Tzar Symeon in the slave trade makes tempting challenges. One of them relates to the disclosure of which exactly unfaithful nations Byzantine captives are sold. Taking other sources of the era and region into consideration the options are limited. Another aspect is related

\footnotetext{
${ }^{73}$ Leonis Choerosphactis Epistolae, p. 176sqq; Theophanis Continuati Chronographia, p. 123; Pseudo -Symeonis Chronographia, p. 176; Leonis Gramatici Chronographia, p. 159; Georgius Monachus Continuatus, p. 140; Symeonis Magistri et Logothetae, p. 277, 123-130; Ioannis Scylitzae Synopsis, p. 177, 20-35. Also: M.J. LeszKA, The Monk..., p. 62-69.

${ }^{74}$ Vitae Luca Iunioris Steiriotis, [in:] FGHB, vol. V, p. 232.

${ }^{75}$ Romani Lacapeni Epistolae, p. 300, 312.
} 
to an attempt to give more density to this economic initiative that is only touched in the letters of Emperor Romanus. Indeed, following the established control over the Danube corridor during $9^{\text {th }}-10^{\text {th }}$ century Bulgaria is pointed out as a key participant determining the intensity and size of the slave stream in Eastern Europe and the region of the Straits ${ }^{76}$. A significant problem facing the affirmation of this logically sounding hypothesis is that it is difficult to be defended with notifications in the narratives of the era ${ }^{77}$. In the interest of objectivity, it should be noted that there is interesting Arab information from the tenth century - in the work Akhbar $a z$-Zaman. The passage describing the Bulgarian export of foreign slaves needs further clarification ${ }^{78}$. Given the discrepancies in the modern translation it is best to look at the Arabic original, and till then there should be taken only general information that the residents of Danubian Bulgaria know this type of trade and have information about markets nearby. More important is the question of what makes the captured imperial subjects to be enslaved and sold outside the country. Unfortunately, Emperor Romanus I does not pay attention to the reasons and one can only speculate. The assumptions vary in a wide range: from maintaining good relations with the neighbors in the vulnerable northeast direction, providing means and pursuit of economic benefits, eliminating the inconveniences of prolonged detention of a large group of people, etc. This, however, does not explain why they are not proposed as a ransom to the ruling ones in Constantinople. Perhaps among the motives of the Bulgarian ruler is the desire that they do not return to the Empire. The latter one refers to deliberate depopulation of the Byzantine possessions in order to limit their resistance possibilities.

Actually the ways to return the warriors and captured civilians without the assistance of the imperial authorities are very limited. A part of the captured ones do not fall within the frameworks of the agreements of exchange, release and redemption and remain in Bulgaria for a long time or till the end of their lives. Even the rough number of those unreturnable captives might never be realized. But modern day scholars are not completely helpless due to the available historical database. A substantive part of information comes from the hagiographical literature. A special case of the return of a representative of the Byzantine elite, closed with fifty other prominent captives is described in the Life of Peter the Patrician. Given the peculiarities of hagiographic literature, despite the coincidence of names, title and

\footnotetext{
${ }^{76}$ Cf. J. Henning, Gefangenenfesseln im slawischen Siedlungsraum und der europäischen Sklavenhandel im 6. bis 12. Jahrhundert. Archäologisches zum Bedeutungswandel von "skläbos-sakāliba-slavus", Ge 70, 1992, p. 403-426; F. CurTA, East Central Europe, EME 12.3, 2003, p. 290-291.

${ }^{77}$ M. McCormick, Complexity, chronology and context in the early medieval economy, EME 12.3, 2003, p. 313-314.

${ }^{78}$ А. ГАРКАви, Сказания мусульманских писателей о Славянах и о Русских (с половины VII века до Х века по Р.Х.), Санкт-Петербург 1870, p. 126, an. 6. About two recent translations, different from one another: Р. ЗАимовА, Арабски извори за българите, София 2000 [= ББВ, 24], p. 36; В. ГюзЕлев, Покръстване и християнизация на българите, София 2006 [= ББВ, 63], р. 217.
} 
managerial position, his identification with the mentioned in Theophanes' Chronography patrician Peter - according to the chronicler, who was killed along with other associates of Emperor Nicephorus I in the ravines of Haemus is subjected to doubt $^{79}$. The same moment with a miraculous release of prisoners of war among Bulgarians during $9^{\text {th }}$ and the following $10^{\text {th }}$ century, appeared in Life of Ioannitzes and the miraculous stories dedicated to St. George ${ }^{80}$. This type of texts, even when relying on real time with captivity and handling with specific individuals and events are a serious challenge for researchers. It is possible to put a specious curtain not to recognize awkward for placarding contacts with the enemy or payment of large sums of money, but one cannot help but recognize that they reproduce the moment with releasing Apostle Peter from the dungeon of Herod the King, described in the Acts of Apostles 12, 3-11.

Under the whole conditionality, the clues about the stay in Bulgarian captivity after the Battle of Achelous (August, 20 917) in one of the miraculous stories about St. George, interesting information about the fate of prisoners of war is present. The inability to purchase or exchange them is generally due to falling into private hands. According to descriptions of the hagiographer, in dividing the captives, the young Byzantine George goes to a Bulgarian aristocrat who owns a large household with many servants and slaves ${ }^{81}$. Although it is about unfolding a hagiographic topos, it may be noted that the flow of captives, distributed as part of the booty, does not necessarily flow only in the lands of representatives of the higher social strata in the First Bulgarian state. In the Old Bulgarian hagiographic cycle The Tale of the Iron Cross it is mentioned that there are subjects even in properties that do not belong to aristocrats and can hardly be defined as lordly mansions. The text does not indicate explicitly that it comes to prisoners of war, but there are details that give rise to such a hypothesis. More important in this case is that in the smaller properties in the provinces the forced labor of the prisoner of war is not inapplicable, despite the limited resources of conventional warriors - peasants and craftsmen in their peaceful life ${ }^{82}$.

One should consider what the status of these non-returnees is from the surroundings of the ones caught up in Bulgarian captivity. The first explanation that comes to mind is that they are enslaved and the short notices engaging Bulgarians in slave trade does not exclude such a possibility. Without the least denying that

\footnotetext{
${ }^{79}$ Vita Petri Patricii, [in:] FGHB, vol. IV, p. 119. Compare with: Theophanes, p. LX; 655; 658, an. 4; 673. ${ }^{80}$ Vita Ioannicii, [in:] FGHB, vol. IV, p. 134, 140; Miraculum S. Georgii, [in:] FGHB, vol. V, p. 62-63.

${ }^{81}$ Although it is about a criminal act and slave-hunting, not a prisoner of war, the Life of St. Blaise of Amorion also points to the farms and homes of Bulgarian boyars after the Conversion - Vita Blasii Amoriensis, [in:] FGHB, vol. V, p. 14-17; В. ГюзЕлев, Средновековна България в светлината на нови извори, София 1981, p. 51-60.

${ }^{82}$ А.А. Турилов, „Не где князь живет, но вне” (Болгарское общество кониа ІХ века в „Сказании о железном кресте”), Слав 2, 2005, р. 24; Я. Христов, Щрихи към „Сказание за железния крғст”, Благоевград 2012, p. 115-118.
} 
Early Medieval Bulgaria was also a slave-owning society, it should be acknowledged that the stored information is an evidence for two essential features. The first one is that a part of the slavery is export-oriented, i.e. the enslaved by Bulgarians are directed outside the First Bulgarian state. The second point is the very slavery situation. Chrestomathically famous is the statement of Strategikon related to the personality of Emperor Maurice (582-602) that the captives among Slavic groups north of the Danube River in the $6^{\text {th }}$ century are only temporarily kept in slavery and have the opportunity to be redeemed and return to their homes or remain wholly free in their new abodes. To what extent this practice, known from the time of the barbarian invasions on the Balkans is also used in the First Bulgarian state in $8^{\text {th }}$ and first half of $9^{\text {th }}$ century is difficult to answer. The time after 865 looks more different, when part of the Byzantine legal experience becomes available to the converted Bulgarian society ${ }^{83}$. Among the texts, regardless of the discussions, the Закон' соүдныи мюдыми naturally stands out. In Chapter 19 there it is particularly noted that enemy captives were enslaved and sold. However, the pronounced opportunity for the person deprived of their freedom to recover an amount of money in order to be released from the position of a slave and return home, should not be left out. It has long been noted that in spite of the discrepancies in the price fixed for redemption, this is a relatively accurate recreation of the meaning of the provisions in item VIII, 6 of the $E c \log u e^{84}$. The very point of enslavement and redemption of prisoners of war should not be considered in isolation and without attention on the Byzantine primary source ${ }^{85}$. The relation, however, is not absolute. In Законъ соүдныи людынть two groups of titles are noticed. One covers those that are translations without changing the meaning and (or) the content of borrowed texts. The second one covers the titles with a free attitude towards the original. It is the latter ones that are particularly important because of crimes for which the mentioned Byzantine law monument enacts a penalty of mutilation, enslavement is provided in the early translatory and compilatory Slavonic law code ${ }^{86}$.

The mentioned various aspects of the fate of prisoners of war in Early Medieval Bulgaria are devoid of the ambition to include the whole complex and diverse mixture of policies of the dominant elite and practices of the popular level in the specific area. At this stage the preliminary remarks rather allow highlighting

\footnotetext{
${ }_{83}$ Р. Чолов, Византийското право..., р. 546-556; Д. НАЙдЕНОвА, Правните паметници..., p. 136-163; ЕАDЕм, Преводни византийски законови текстове..., p. 30-36.

${ }^{84}$ С. ТроИцкий, Святой Мефодий..., р. 90; М. Андревв, Към въпроса за произхода и същностma..., p. 11-12.

${ }^{85}$ Y. Rotman, Byzantine Slavery..., p. 33.

${ }^{86}$ К. ИлИЕВСКА, Закон'ъ соүдныи людымн'ъ..., р. 76, 86-90, 103-107, 163, 176-186, 200-212; К. МАКсимович, Древнейший памятник..., р. 26-33, 37-52.
} 
of contours, a significant Bulgarian experience and traditions to take captives and take advantage of military and tactical, political and economic benefits out of them, even in an adverse development of military actions with the enemy. In the Early Middle Ages prisoners of war (in the broadest medieval sense) are an integral part of the efforts to achieve the political objectives of the Bulgarian rulers. Response mechanisms against prisoners of war are highly dependent on the course of the conflict and their attitude towards their own warriors and subjects caught up in enemy hands. They include a wide range of solutions. They are grouped into three main areas: the first one refers to killing (and/or mutilation) of prisoners of war. The terms of clashes in medieval societies do not contribute much to a merciful attitude towards the one fallen into enemy captivity. However, it is worth mentioning the striving after winning a battle to reduce fast and permanently the military potential of the enemy, while not wasting time and resources, and a tactical advantage for the ultimate success in the war is used. Besides the need for a rapid deployment of the victorious army, in order to achieve the strategic goals of the Bulgarian command, the purely psychological aspect of mass executions should not be underestimated either. They demoralize the enemy and lead to failure of new risks in open battles; the second main line is connected with preserving the lives of the captives, with the aim of a possibly quicker retrieval of a direct profit by offering them as a ransom or sale; the third group of measures is due to the fact that an immediate effect is not always haunted. It involves mostly long-term solutions - closing captives for an indefinite period of time until achieving the desired peace and exchange of tribesmen found in the hands of the enemy, as well as an attempted integration of captured and kidnapped people in the economic and military-political structures of the Bulgarian state.

\section{Bibliography}

\section{Sources}

Agathias, The Histories, ed. et trans. J.D. Frendo, Berlin 1975.

Annales anonymi presbyteri de Dioclea, [in:] FLHB, vol. III, p. 170-179.

Constantine Porphyrogenitus, De administrando imperio, vol. I, ed. et trans. G. Moravcsik, R.J.H. JENKINS, Washington 1967.

Constantini Porphyrogeniti, II. De administrando imperio, [in:] FGHB, vol. V, p. 198-220.

Genesios, On the Reigns of the Emperos, ed. et trans. A. Kaldellis [= BAus, 11], Canberra 1998.

Georgii Monachi Chronikon, [in:] FGHB, vol. IV, p. 42-57.

Georgius Monachus Continuatus, [in:] FGHB, vol. VI, p. 133-158.

Ioannis Scylitzae Synopsis Historiarum, rec. I. Thurn, Berolini-Novi Eboraci 1973.

Ioannis Zonarae Epitomae Historiarum Libri XVIII, [in:] FGHB, vol. VII, p. 149-207. 
Joannis Geometrae Carmina, [in:] FGHB, vol. V, p. 317-321.

John Skylitzes, A Synopsis of Byzantine History, 811-1057, trans. J. WortLey, Cambridge 2010.

Laudatio Photii Thessalonicensis, [in:] FGHB, vol. V, p. c. 314-316.

Leonis Choerosphactis Epistolae, [in:] FGHB, vol. IV, p. 175-184.

Leonis Gramatici Chronographia, [in:] FGHB, vol. V, p. 140-168.

Menologium Basilii, [in:] FGHB, vol. VI, p. 48-64.

Miraculum S. Georgii, [in:] FGHB, vol. V, p. 60-67.

Mošın V., Ljetopis popa Dukljanina, Zagreb 1950.

Narratio anonyma e codice Vaticano, [in:] FGHB, vol. IV, p. 10-15.

Nicholas I Patriarch of Constantinople, Letters, Greek text and English translation, ed., R.J.H. Jenkins, L.G. Westernik, Washington 1973.

Nicolai Constantinopolitani Archiepiscopi Epistolae, [in:] FGHB, vol. IV, p. 185-297.

Nikephoros, Patriarch of Constantinople, Short History, ed., trans. et comm. C. Mango, Washington 1990.

Petкov K., The Voices of Medieval Bulgaria, Seventh-Fifteenth Century. Records of a Bygone Culture, Leiden-Boston 2008 [= ECEEMA, 5].

Procopius, History of the Wars, vol. V, ed. et trans. H.B. Dewing, London-Cambridge Mass. 1962. Pseudo-Symeonis Chronographia, [in:] FGHB, vol. V, p. 170-182.

Romani Lacapeni Epistolae, [in:] FGHB, vol. IV, p. 298-314.

Scriptoris incerti historia de Leone Armenii Bardae filio, [in:] FGHB, vol. IV, p. 16-24.

Sinaxarium ecclesiae Constantinopolitanae, [in:] FGHB, vol. V, p. 281-294.

Suidae Lexicon, [in:] FGHB, vol. V, p. 308-310.

Symeonis Magistri et Logothetae Chronicon, rec. S. WAHLGREN, Berolini-Novi Eboraci 2006.

The Chronicle of Theophanes Confessor: Byzantine and Near Eastern History AD 284-813, trans. C. MAngo, R. ScotT, Oxford 1997.

The History of Leo the Deacon: Byzantine Military Expansion in the Tenth Century. ed. et trans. A.-M. Тацвот, D.F. Sullivan, Washington 2005.

Theophanis Confessoris Chronographia, [in:] FGHB, vol. III, p. 226-289.

Theophanis Continuati Chronographia, [in:] FGHB, vol. V, p. 107-139.

Vita Blasii Amoriensis, [in:] FGHB, vol. V, p. 14-17.

Vita Ioannicii, [in:] FGHB, vol. IV, p. 132-140.

Vita Lucae Iunioris Steiriotis, [in:] FGHB, vol. V, p. 231-234.

Vita Petri Patricii, [in:] FGHB, vol. IV, p. 119.

Zakon sudnyi liudem. (Court Law for the People), ed. et trans. H.W. Dewey, A.M. KLeimola, MSM $14,1977$.

БЕшевлиев В., Първобългарски надписи, ${ }^{2}$ София 1992.

ГАРкАви А., Сказания мусульманских писателей о Славянах и о Русских (с половины VII века до Х века по Р.X.), Санкт-Петербург 1870.

ГюзЕлев В., Покръстване и християнизация на българите, София 2006 [= ББВ, 63]. 
Гюзелев В., Средновековна България в светлината на нови извори, София 1981.

Добавки на епископ Михаил Деволски от 1118 г. към „Исторически свод” на Йоан Скилица (XI в.), [in:] Извори за средновековната история на България (VII-XV в.) в Австрийските ръкописни сбирки и архиви, vol. I, ed. В. Гюзелев, София 1994, p. 45-57.

ЗАимова Р., Арабски извори за българите, София 2000 [= ББВ, 24].

ИлиЕвСКА К., Законъ соудныи людьмъ, Скопје 2004.

Кекавмен, Советы и рассказы. Поучение византийского полководия ХІ века, ed. et trans. Г.Г. ЛитАвРин, ${ }^{2}$ Санкт-Петербург 2003.

КОНСТАНТИН БАГРЯНОРОДНЫЙ, Об Управлении Империей. ed. et trans. Г.Г. ЛитАвРИН, А.П. НовоСЕЛЬЦЕв, Москва 1991.

КонСтАНтин ПоРФИРОГенит, Спис о народима, [in:] FBHPJS, vol. II, p. 9-74.

Мијушковит С., Љетопис попа Дукљанина, Београд 1988.

Продолжатель Феофана. Жизнеописания византийских иарей, ed. Я.Н. ЛюбАрский, ${ }^{2}$ СанктПетербург 2009.

Шишић Ф., Летопис попа Дукљанина, Београд-Загреб 1928.

\section{Secondary Literature}

Bова I., The Pannonian Onogurs, Khan Krum and the Formation of the Bulgarian and Hungarian Polities, BHR 11.1, 1983, p. 73-76.

BožILOv I., One of Omourtag's Memorial Inscriptions, BHR 1, 1973, p. 72-76.

BRowning R., Byzantines in Bulgaria - late $8^{\text {th }}$ - early $9^{\text {th }}$ Centuries, [in:] Studia Slavico-Byzantina et Mediaevalia Europensia. In memoriam Ivan Dujčev, vol. I, ed. P. Dinekov et al., Sofia 1988, p. 32-36.

CurTa F., East Central Europe, EME 12.3, 2003, p. 283-291.

Curta F., Were There any Slavs in Seventh-Century Macedonia?, Исто 47.1, 2012, p. 61-74.

Follieri E., DujČEv I., Un'acolutia inedita per i martiri di Bulgaria dell' anno 813, B 33, 1963, p. 71-106.

Gallagher C., Church Law and Church Order in Rome and Byzantium: A Comparative Study, Aldershot 2002 [= BBOM, 8].

Gillingham J., Christian Warriors and the Enslavement of Fellow Christians, [in:] Chevalerie et Christianisme aux XII et XIII' siècles, ed. M. Aurell, G. Girbea, Rennes 2011, p. 237-255.

Gillingham J., Women, Children and the Profits of War, [in:] Gender and Historiography. Studies in the Earlier Middle ages in Honour of Pailine Stafford, ed. J.L. Nelson, S. Reynolds, S.M. Johns, London 2012, p. 61-74.

GJuzelev V., Bulgarisch-Fränkische Beziehungen in der ersten Hälfte des 9 jhs, BBg 2, 1966, p. 15-39.

Gračanin H., Bulgari, Franci i Južna Panonija u 9. stoljeću. Reinterpretacija povijesnish izvora, [in:] Hrvati i Bugari kroz stoljeća. Povijest, kultura, umetnost i jezik. Zbornik radova sa znanstvenog skupa održanog u Zagrebu i Đakovu, 23-24 rujna 2010, ed. D. KARBIć, T. Luetić, Zagreb 2013, p. 3-22.

Haldon J., Warfare, State and Society in the Byzantine World, 565-1204, London 1999.

HeNnING J., Gefangenenfesseln im slawischen Siedlungsraum und der europäischen Sklavenhandel im 6. bis 12. Jahrhundert. Archäologisches zum Bedeutungswandel von "skläbos-sakāliba-slavus", Ge 70, 1992, p. 403-426. 
Koder J., Stouraitis I., Byzantine Approaches to Warfare ( $6^{\text {th }}-12^{\text {th }}$ centuries). An Introduction, [in:] Byzantine war ideology between Roman imperial concept and Christian religion, ed. J. Koder, I. Stouraitis, Vienna 2012, p. 9-15.

Komatina P., The Slavs of the Mid-Danube Basin and the Bulgarian Expansion in the First half of the $9^{\text {th }}$ century, ЗРВИ 47, 2010, p. 55-82.

Leszka M.J., The Monk versus the Philosopher: From the History of the Bulgarian-Byzantine War 894-896, SCer, 1, 2011, p. 55-70.

McCormick M., Complexity, chronology and context in the early medieval economy, EME 12.3, 2003, p. 307-323.

Miкцoshich F., Lexicon Palaeoslovenico-Graeco-Latinum, Vindobonae 1862-1865.

Mladjov I., Trans-Danubian Bulgaria: Reality or Fiction, ByzS 3, 1998, p. 85-128.

Morillo S., A General Typology of Transcultural Wars - The Early Middle Ages and Beyond, [in:] Transcultural Wars from the Middle Ages to the $21^{\text {st }}$ Century, ed. H.-H. KontüM, Berlin 2006, p. 29-42.

Morrisson C., Cheynet J.-C., Prices and Wages in the Byzantine World, [in:] The Economic History of Byzantium: From the Seventh through the Fifteenth Centuries, vol. II, ed. A. LAïou et al., Washington 2002, p. 815-878.

Najdenova D., Cyrillo-Methodian Juridical Heritage in Mediaeval Bulgaria, [in:] Poznávanie kultúrneho dedičstva sv. Cyrila a Metoda. Monografia príspekov z medzinárodnej konferencii Nitra, 3 júl 2007, ed. J. Michalov et al., Nitra 2007, p. 76-93.

Olajos T., Le Lexique "Souda" a propos du khan bulgare Kroum et des Avars, [in:] Polihronia: Сборник в чест на проф. Иван Божилов, еd. И. Илиев, София 2002, p. 230-235.

Papastathis Ch.K., On the «Saint Constantine» of the Zakon Sudnyj Ljudem, Bsl 56.3, 1995, p. 557-559.

Pohl W., A Non-Roman Empire in the Central Europe: The Avars, [in:] Regna and Gentes: The Relationship between Late Antique and Early Medieval Peoples and Kingdoms in the Transformation of the Roman world, ed. H.W. GoETz, Leiden-Boston 2003 [= TRW,13], p. 571-595.

Poнl W., Die Awaren. Ein Steppenvolk im Mitteleuropa 567-822 n. Chr., München 1988.

Procházka V., Materiály a diskuse. Tři nové marné po kusy o bulharského a makedonského pưvodu Zakona sudného ljudem, Sla 33, 1964, p. 262-267.

Procházka V., Le Zakonz sudnyjo ljudımz et la Grande Moravie, Bsl 28, 1967, p. 359-375; 29.1, 1968, p. 112-150.

Ramadān A.M.A., The Treatment of Arab Prisoners of War in Byzantium, $9^{\text {th }}-10^{\text {th }}$ Centuries, AIs 43, 2009, p. 155-194.

Rotman Y., Byzantine Slavery and the Mediterranean World, trans. J.M. TodD, Cambridge 2009.

Rotman Y., Captif ou esclave? Entre marché d’esclaves et marché de captifs en Méditerranée medievale, [in:] Les esclavages en Méditerranée. Espaces et dynamiques économiques, ed. F.P. GuILLÉN, S. Trabelsi, Madrid 2012, p. 25-46.

Simeonova L., Foreigners in Tenth-Century Byzantium: A Contribution to the History of Cultural Encounter, [in:] Strangers to Themselves: The Byzantine Outsider. Papers from the Thirty-second Spring Symposium of Byzantine Studies, University of Sussex, Brighton, March 1998, ed. D.C. Smythe, Aldershot 2000 [= SPBS.P, 8], p. 229-244.

Simeonova L., In the Depths of Tenth-Century Byzantine Ceremonial: The Treatment of Arab Prisoners of War at Imperial Banquets, BMGS 22, 1998, p. 75-104. 
Sophoulis P., "The Chronicle of 811", the Scriptor incertus and the Byzantine-Bulgar wars in the early ninth century, BMd 1, 2010, p. 377-384.

Sophoulis P., Byzantium and Bulgaria, 775-831, Leiden-Boston 2012 [= ECEEMA, 16].

Sophoulis P., Containing the Bulgar threat: Byzantium's search for an ally in the former Avar territories in the Early Middle ages, BMd 2, 2011, p. 399-407.

Sophoulis P., New Remarks on the History of Byzantine-Bulgar Relations in the Late Eighth and Early Ninth Centuries, Bsl 67.1/2, 2009, p. 119-138.

Sounders C., Sexual Violence in Wars - The Middle Ages, [in:] Transcultural Wars from the Middle Ages to the $21^{\text {st }}$ Century, ed. H.-H. KortüM, Berlin 2006, p. 151-163.

Stepanov Ts., The Bulgars and the Steppe Empire in the Early Middle Ages: the Problem of the Others, Leiden-Boston 2010.

STEPHENSOn P., "About the emperor Nikephoros and how he leaves his bones in Bulgaria": A context for the Controversial Chronicle of 811, DOP 60, 2006, p. 87-109.

Stouraitis I., 'Just War'and 'Holy War' in the Middle Ages. Rethinking Theory through the Byzantine Case-Study, JÖB 62, 2012, p. 227-264.

Treadgold W., Byzantium, the Reluctant Warrior, [in:] Noble Ideals and Bloody Realities: Warfare in the Middle Ages, ed. N. Christie, M. Yazigi, Leiden-Boston 2006, p. 209-233.

VAšICA J., K lexiku Zakona sudného ljudem, SR 10.1/4, 1957, p. 61-66.

VAšICA J., K otázce pưvodu Zakona sudného ljudem, Sla 30, 1961, p. 1-19.

VAšICA J., Origine Cyrilo-Methodienne du plus ancient code slave dit «Zakon Sudnyj Ljudem», Bsl 12, 1951, p. 154-174.

АндреЕв М., Законъ соудый людьмъ - стробългарски правен паметник, ПМи 1, 1958, р. 13-27.

АндреЕв М., Към въпроса за произхода и същността на Законъ соудый людьмъ, ГСУ.ЮФ 49, 1957, p. 1-60.

Андревв М., Нови проучвания и нови теории относно произхода на Законъ соудый пюдьмъ, ГСУ.ЮФ 55, 1964, p. 27-83.

АТАнасов Г., Българо-хазарската граниия и българо-хазарската враждебност от края на VII до средата на IX век, [in:] Българи и хазари през ранното средновековие, еd. Ц. СтепАнов, София 2003, p. 92-113 [= ББВ, 43].

БЛАГова Э., ЦЕЙтЛИН Р.М., ВЕчеРКА Р., Старославянский словарь. (По рукописям Х-ХІ веков), Москва 1994.

Божилов И., ГюзЕлев В., История на България в 3 тома, vol. I, История на средновековна България VII-XIV век, София 1999.

ГАнев В., Законъ соудный тюдьмъ. Правно-исторически и правно-аналитични проучвания, София 1959.

Гюзелев В., Българо-византийски диптих, [in:] Studia protobulgarica et mediaevalia europensia в чест на проф. В. Бешевлиев, еd. К. Попконстантинов et al., София 2003, p. 23-30.

Даничић Ћ., Рјечник из кюижевних старина српских, vol. II, Л-П, Београд 1863.

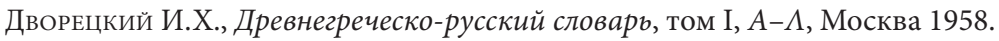

Дьяченко Г., Полный церковно-славянский словарь, Москва 1900.

Живковит Т., Јужни словени под византијском власћу 600-1025, Београд 2007. 
ЗлАТАРски В., История на бблгарска държава през средните векове, vol. 1, pars 1, Епоха на хуно-българското надмощие (679-852), София 1918.

Иванова-Мирчева Д., ДАвиДКОв А., ИкОНомова Ж., Старобългарски речник, vol. II, O-У, София 2009.

МАксимович К.А., Древнейший памятник славянского права «Закон судный людем»: композииия, переводческая техника, проблема авторства, ВВ 61 (86), 2002, р. 24-37.

МАксимович К.А., Законъ соудныи людьмъ. Источниковедческие и тингвистические аспекты исследования славянского юридического памятника, Москва 2004.

Милкова Ф., Законът за съдене на хората - старобългарски паметник, [in:] Втори международен конгрес по българистика, vol. VI, ed. Х. ХРистов, София 1987, p. 692-708.

НАЙденова Д., Правните паметници в Птрвото българско изарство, ИБ 9.1/2, 2005, p. 136-163.

НАЙдеНовА Д., Преводни византийски законови текстове в средновековна Бблгария, СБАН $121.5,2008$, p. 30-36.

Николова Б., Неназован българо-византийски конфликт при хан Омуртаг, Епо 5.1/2, 1997, p. 63-76.

ПАвлов П., Българо-хазарски взаимоотнотения и паралели, [in:] Бблгари и хазари през ранното средновековие, еd. Ц. СТЕПАНОВ, София 2003, p. 114-141 [= ББВ, 43].

Пириватрит С., Дукть, Бугарска и Византија на Јужном Јадрану крајем 10. и почет-ком 11. века, [in:] България и Сърбия в контекста на византийската иивилизация, еd. В. Гюзелев, А. МилТенова, Р. СТАнкова, София 2005, р. 91-99.

Рашев Р., Византийците в България до Покрбстването, [in:] Civitas Divino-Humana. In honorem annorum LX Georgii Bakalov, ed. Цв. СтеПАНов, В. ВАЧковА, София 2004, p. 151-162.

Симеонова Л., Разиифроване на езика на символите: «Реформите» на Лъв VI Мбдри в дворцовия и публичния иеремониал, ИП 5/6, 1999, р. 3-20.

Симеонова Л., Семиотика на унижението: Високопоставени чуждении в имперската столииа през Х век, Род 4, 1996, p. 29-43.

Срезневский И., Материалы для словаря древнерусского языка по письменным памятникам, vol. II, Л-П, Санкт-Петербург 1902.

Станев К., Депортираните ромеи в България 812-837 година, [in:] Оттука започва България. Материали от Втората национална конференция по история, археология и културен туризъм «Пътуване към България», Шумен, 14-16 май 2010, еd. В. ГюзЕлев, Шумен 2011, p. $183-195$.

Станев К., Съдбата на ромейски войници, пленени при разгрома на император Никифор I, [in:] Кюстендилски четения 2007. Заедно или разделени. Европа на съюзите, личностите и регионите, ed. В. СТАнев, София 2012, р. 25-33.

Станев К., Тракия през ранното средновековие, Велико Търново 2012.

СтепАнов Ц., Периферията като вселена, [in:] История на българите: Потребност от нов подход. Преоценки, vol. I, ed. ІDЕм, София 1998, p. 107-121.

Троицки С., Да ли је «Закон судый людем» составио свети Методије или бугарски кнез Борис?, ИЧ $14 / 15,1965$, р. 505-516.

Троицки С., Святой Мефодий как славянский законодатель, [in:] IDEм, Богословские труды, vol. II, Москва 1961, p. 83-141.

Турилов А.А., „Не где князь живет, но вне” (Болгарское общество кониа IX века в „Сказании о железном кресте"), Слав 2, 2005, р. 20-27. 
Филипу Ф., По въпроса за гонението на християни по време на управлението на кан Омуртаг, [in:] Оттука започва България. Материали от Втората национална конференция по история, археология и културен туризбм «Пътуване към България», Шумен, 14-16 май 2010 , ed. В. Гюзелев, Шумен 2011, p. 178-182.

Христов Я., Щрихи към „Сказание за железния крғст”, Благоевград 2012.

Чолов Р., Византийското право в Средновековна България, [in:] Втори международен конгрес по българистика, vol. VI, ed. Х. Христов, София 1987, p. 546-556.

\begin{abstract}
Abstarct. The work is concentrated on the problem of war prisoners in the chronological period of the existance of the so-called First Bulgarian state. The analysis is based predominantly on various Byzantine and selected Latin and Bulgarian sources from the epoch. With some exceptions, mostly for $707 / 708,754 / 755,763 / 764$ and 774 , the notices are concentrated around the events of 811-815/816, $837 / 838$; 894-896, 917-30s and for a moment or two from the period of 971-1018. In his preliminary remarks the author comes to the conclusion that in the Early Middle Ages prisoners of war (in the broadest medieval sense) were an integral part of the efforts to achieve the political objectives of the Bulgarian rulers. Response mechanisms against prisoners of war were highly dependent on the course of the conflict and their attitude towards their own warriors and subjects caught up in enemy hands. They included a wide range of solutions, which could be grouped into three main areas: the first one refers to killing (and/or mutilation) of war prisoners; the second main line was connected with preserving the lives of the captives; the third group of measures was due to the fact that an immediate effect is not always haunted.
\end{abstract}

Keywords: prisoners of war, captives, peace/war studies, the First Bulgarian state, Byzantine-Bulgarian relationships, early medieval history

Yanko M. Hristov

Chair of History South-West Univeristy "Neofit Rilski" 66 Ivan Mihaylov St., U.C. 1 2700 Blagoevgrad, Bulgaria hristiqnko@gmail.com 